\title{
FOLLICULAR FLUID
}

\author{
R. G. EDWARDS \\ Physiological Laboratory, University of Cambridge, Cambridge
}

Follicular fluid is composed partly of secretions from the follicle, and partly of exudates from plasma. Its composition reflects changes in the secretory processes of the granulosa layer and theca interna, and alterations in the components of plasma due to physiological or pathological processes. The presence of follicular fluid in so many species testifies to its potential importance in ovarian physiology, including steroidogenesis, growth of the follicle and ovulation, and maturation of the oocyte and its transport to the oviduct. The fluid can be collected easily, especially as the follicle enlarges, and there has been prolonged interest in its composition and functions.

The source of the fluid in Graafian follicles was discussed widely in early debates, some authorities maintaining that it was produced within the follicle, whereas others believed it to be a transudate of plasma. Such a debate is now spurious, for various components of the fluid almost certainly arise from both sources. The plasma proteins, for example, are found in follicular fluid, yet are unlikely to be synthesized in situ. On the other hand, the high concentrations of steroids and of mucopolysaccharides almost certainly reflect the synthetic activity of the follicular cells. In this review, the properties and components of follicular fluid will be described first, followed by a consideration of the rôle of the fluid in various physiological processes. The early literature has been fully reviewed by Brambell (1960), Zachariae (1959), Moricard (1969) and others.

\section{APPEARANGE AND PHYSICAL PROPERTIES OF FOLLICULAR FLUID}

\section{Size and structure of follicles}

The size of the fully-grown Graafian follicle varies widely between species, from a few millimetres in mice to $5 \mathrm{~cm}$ in the horse, the volume being determined largely by the amount of follicular fluid. The fluid is separated from the blood circulation by two layers of tissue. The granulosa cells lie on the membrana propria, and the structure and properties of the membrane and its cellular lining have been described in detail (e.g. Brambell, 1960; Bjorkman, 1962; Gouézou, 1969; Zamboni, 1972) (PI. 1, Fig. 1a, b). The theca interna lies outside the membrana propria and, unlike the granulosa, is vascularized. The integrity of the fully-grown follicle is undoubtedly determined by the properties of these three layers, although during the earlier stages of growth the granulosa layer is very small, and the theca develops as follicles expand. The contents of the follicle are thus separated from the circulation by cellular and physiological barriers throughout the life of the follicle. Nerve endings to the follicle terminate in the 
theca (Brambell, 1960; Bulmer, 1965), often in association with muscle fibres (Bell, 1972).

Follicular fluid is first seen as a secretion accumulating between the layers of granulosa cells in growing follicles. Initially, this secretion is presumably an extracellular product of the granulosa cells, as judged by autoradiographic studies of their synthetic activity (Boström \& Odeblad, 1952; Zachariae, 1957). Follicles evidently become especially responsive to FSH and perhaps LH at about this stage of development, and develop into fully-grown Graafian follicles given the correct stimulus, although the earlier stages of follicular growth may also be dependent on gonadotrophins. The fully-grown Graafian follicle begins its preovulatory changes under the influence of the $\mathrm{LH}$ surge, expands and then ruptures at ovulation. The components of follicular fluid could thus alter during growth and expansion of the follicles. Most attention has been given to the fluid of expanding and fully-grown follicles.

\section{Physical properties of the fluid}

A word of caution is necessary about the collection of follicular fluids. They should preferably be aspirated from follicles in the intact animal rather than from excised ovaries, in order to avoid degenerative changes in the tissue (e.g. see Table 3). Follicular fluid is a slightly viscous, straw-coloured solution. Most investigators report its $\mathrm{pH}$ to be above $7 \cdot 0$, and similar to plasma (Lutwak-Mann 1954; Zachariae \& Jensen, 1958). A recent report gave the $\mathrm{pH}$ of human fluid as 7.267, which was lower than that of serum (Shalgi, Kraicer \& Soferman, 1972a); the $\mathrm{pCO}_{2}$ was the major factor controlling the $\mathrm{pH}$ of the fluid, although there appeared to be a source of non-volatile acid in it which also decided the $\mathrm{pH}$.

Our own studies on the osmotic pressure of human follicular fluid are shown in Table 1. Fluids aspirated during laparoscopy from follicles in the final stages

Table 1. Osmotic pressure and concentration of sodium, potassium and protein in human follicular fluids and serum

\begin{tabular}{|c|c|c|}
\hline & $\begin{array}{l}\text { Follicular } \\
\text { fluid }\end{array}$ & Serum \\
\hline $\begin{array}{l}\text { Sodium (mequiv/l) } \\
\text { Potassium (mequiv/l) } \\
\text { Osmolality (mOsmol/kg) } \\
\text { Protein (mg/ml) }\end{array}$ & $\begin{aligned} & 147 \cdot 8 \pm 8.9 \\
& 5 \cdot 2 \pm 0 \cdot 5 \\
& 279 \cdot 8 \pm 7 \cdot 0 \\
& 35 \cdot 8^{*}\end{aligned}$ & $\begin{array}{r}150.5 \pm 8.9 \\
5.7 \pm 0.3 \\
278.9 \pm 1.3\end{array}$ \\
\hline
\end{tabular}

* Manarang-Pangan \& Menge (1971).

of their growth had an osmotic pressure very slightly above that of serum collected simultaneously. In another study, the osmotic pressure of human follicular fluid from excised ovaries was found to be identical with that of plasma (Shalgi, Kraicer \& Soferman, 1972b). Earlier estimates implied that the osmotic pressure of unstimulated follicles was much lower than that of plasma or of fluid from preovulatory follicles (Smith, 1937). 
There could be an additional increment in the fluids of various follicles due to colloid osmotic pressure, for large quantities of colloidal material are found in some follicles. The colloid osmotic pressure of bovine and mare follicular fluid was measured by Zachariae \& Jensen (1958), and found to be equivalent to 21.5 $\mathrm{cm}$ of water. These authors developed a theory to explain the preovulatory changes in follicles, based on an increase in colloid osmotic pressure and a decrease in viscosity arising through the depolymerization of mucopolysaccharides, a point discussed later in this review.

Other physical properties of follicular fluid have been discussed by Gouézou (1969). It has the properties of a polymer and semi-conductor. Certain components will crystallize to give a typical three-dimensional pattern.

\section{NON-HORMONAL COMPONENTS OF FOLLICULAR FLUID}

\section{Inorganic components}

The levels of various elements in follicular fluid are close to those found in serum. Some differences have been noted, their significance remaining unknown : they could reflect variations due to the method of sampling or the source of tissue. Two ions of considerable interest are $\mathrm{Na}^{++}$and $\mathrm{K}^{+}$, for their concentrations will largely determine the osmotic pressure of the fluid. In our own studies (Table 1) on fluid aspirated from preovulatory human follicles, levels of the two ions were similar although more variable than those in serum, and the same conclusion was drawn from analyses of fluid from growing follicles of excised ovaries (Shalgi et al., 1972a, b). In earlier work on the cow, more potassium and, to a less extent, sodium were found in the follicular fluid than in serum (Luiwak-Mann, 1954; Olds \& VanDemark, 1957; Pascu, Mihai \& Lunca, 1969) (Table 2), especially in the fluid of the growing follicles. The fluid in these

Table 2. Levels of sodium ( $\mathrm{g} / \mathrm{litre}$ ) and potassium $(\mathrm{mg} / 100 \mathrm{ml}$ ) in serum and the fluid of follicles at different stages of the oestrous cycle of the cow (modified after Pascu et al., 1969)

\begin{tabular}{l|c|c|c|c}
\hline & \multicolumn{2}{|c|}{ Sodium } & \multicolumn{2}{c}{ Potassium } \\
\cline { 2 - 4 } & $\begin{array}{c}\text { Follicular } \\
\text { fuid }\end{array}$ & Serum & $\begin{array}{c}\text { Follicular } \\
\text { fluid }\end{array}$ & Serum \\
\hline Pro-oestrus & $2 \cdot 7 \pm 0 \cdot 1$ & $2 \cdot 6 \pm 0 \cdot 1$ & $22 \cdot 6 \pm 1 \cdot 3$ & $17 \cdot 8 \pm 0 \cdot 3$ \\
Oestrus & $2 \cdot 9 \pm 0 \cdot 1$ & $2 \cdot 8 \pm 0 \cdot 1$ & $26 \cdot 1 \pm 3 \cdot 1$ & $18 \cdot 6 \pm 1 \cdot 1$ \\
Dioestrus & $3 \cdot 1 \pm 0 \cdot 1$ & $3 \cdot 0 \pm 0 \cdot 1$ & $24 \cdot 6 \pm 1 \cdot 3$ & $16 \cdot 4 \pm 0 \cdot 5$ \\
Cystic follicles & $2 \cdot 8 \pm 0 \cdot 1$ & $2 \cdot 7 \pm 0 \cdot 1$ & $18 \cdot 4 \pm 1.2$ & $17 \cdot 4 \pm 0.8$ \\
\hline
\end{tabular}

may be more typical of a cellular secretion than in older follicles, and some of these authors suggest that $\mathrm{K}^{+}$is secreted by the granulosa cells during follicular expansion. Magnesium, chloride, calcium, zinc, copper and inorganic phosphate have been measured in cow follicular fluid (Lutwak-Mann, 1954; Pascu and his colleagues, 1968; Petkov, Antanov \& Dzhurova, 1969) and values were in general fairly similar to those of serum. 
Gases in human follicular fluid were estimated by Shalgi et al. (1972a), using a micro-electrode system. Oxygen tension was variable over a nine-fold range, averaging $54 \mathrm{~mm} \mathrm{Hg}$. Variability between follicles of individual patients was as great as variation between patients, indicating that the follicles themselves determined the variations in oxygen tension. Values for $\mathrm{CO}_{2}$ were less variable, and were determined partly by the activity of the follicle; at an average of 35 $\mathrm{mm} \mathrm{Hg}$, they were similar to the accepted normal values for serum.

Smaller molecules in plasma become rapidly equilibrated with follicular fluid (Text-fig. 1). Tritiated water reached equilibrium levels in human follicular fluid within 15 and 25 min after an intravenous injection (Peckham \& Kiekhofer,

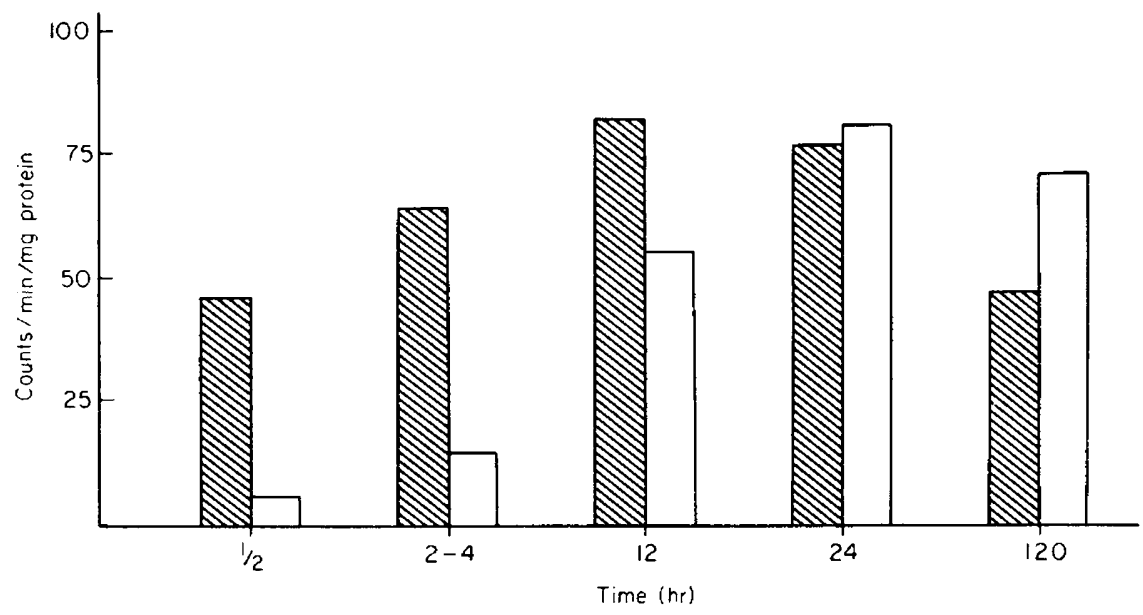

TExT-FIG. 1. Transmission of ${ }^{14} \mathrm{C}$-leucine from the circulation into the fluid of ovarian cysts in rats (Yatvin \& Leathem, 1964). Hatched columns, serum; open columns, cyst fluid.

1959). Labelled elements such as ${ }^{131} \mathrm{I}$ and other compounds were in equilibrium within $4 \mathrm{hr}$ and were retained longer in follicular fluids (von Kaulla, Aikawa \& Pettigrew, 1958). Compounds such as Evans blue rapidly enter follicles, especially those approaching ovulation, so that a differential uptake is noted between these and smaller follicles within a few minutes (Zachariae, 1958).

\section{Carbohydrates, mucopolysaccharides, lipids}

Biochemical analyses of cow follicular fluid revealed that glucose at a concentration of $40 \mathrm{mg} \%$ comprised about three-quarters of the total carbohydrate, other compounds such as fructose being present in minor quantities (LutwakMann, 1954); lactic acid and cholesterol were also identified in the fluids (Table 3). Levels of protein-bound hexoses and of fucose were lower in bovine follicular fluid than in plasma (Caravaglios \& Cilotti, 1957), more protein-bound hexose being found in the fluid of smaller follicles in the cow and mare (Zachariae \& Jensen, 1958). Glucose levels in cow follicular fluid were raised during prooestrus (Pascu et al., 1968). Ribulose has been identified in human follicular fluid (Hayashi, Hayashi, Amano \& Yanagisawa, 1973). Various lipids were also 
Table 3. Some estimates of carbohydrates $(\mathrm{mg} / 100 \mathrm{ml})$ in the fluids of cow and mare follicles

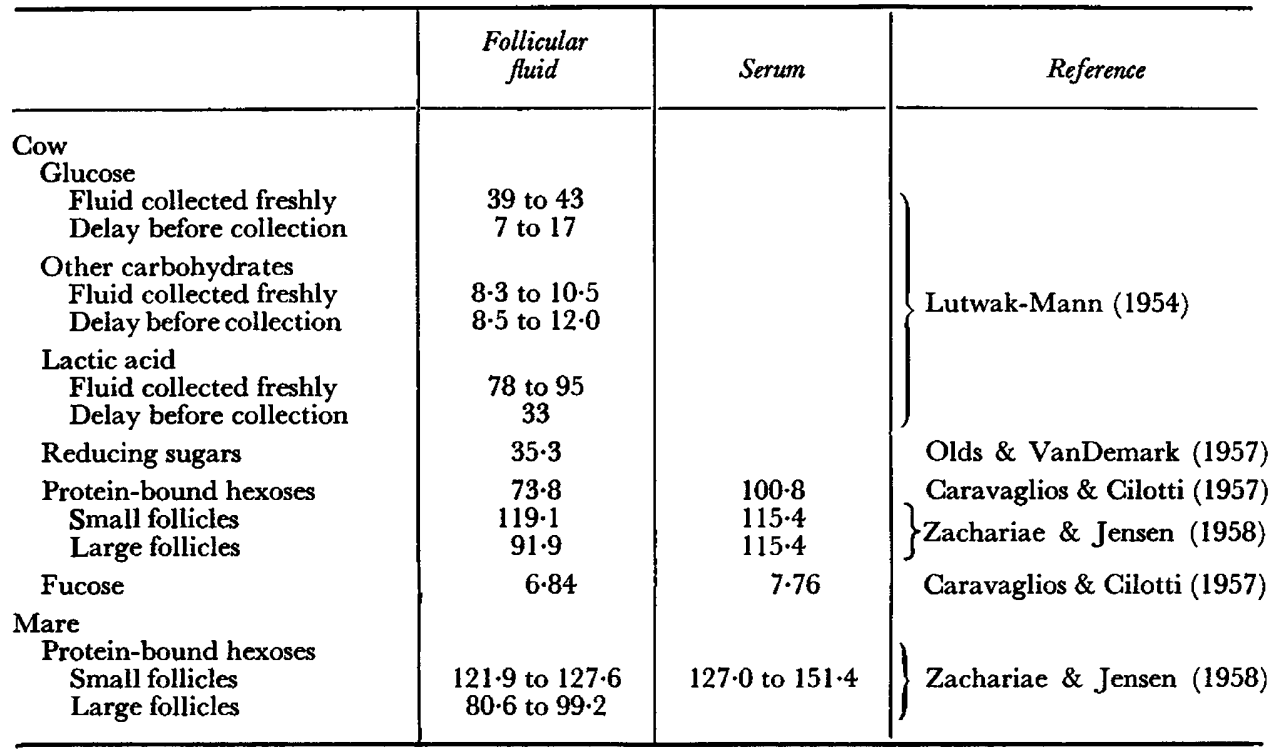

detected in cow fluids, along with 'seromucoids' and mucopolysaccharides (Zachariae \& Jensen, 1958); and mucopolysaccharides are found in rabbit follicular fluid (Odeblad, 1954). Levels of vitamin C in bovine follicular fluid are highest at oestrus, and consistently greater than in serum (Pascu, Suteanu \& Lunca, 1970). Vitamins and co-enzymes were not detected in fluids from small human follicles (Cerletti \& Zichella, 1961).

Histochemical tests have also revealed the presence of mucopolysaccharides in follicular fluid (Jacoby, 1962), and the type and distribution of these compounds in the follicle. In ripening bovine follicles, the intercellular substance of the granulosa cells and the follicular fluid were strongly metachromatic after staining with toluidine blue (Odeblad \& Boström, 1953; Zachariae \& Jensen, 1958). A decline in the degree of staining as ovulation approached (Zachariae \& Jensen, 1958) was ascribed to an increasing sensitivity of mucopolysaccharides to hyaluronidase. In contrast, Braden (1952) suggested that the decline in staining was due to the distension of the follicle.

Labelled sulphate is taken up by follicles of the rabbit and other species at particular stages of their development (Odeblad, 1952, 1954; Odeblad \& Boström, 1953; Gothie, 1954; Zachariae, 1957). Small follicles without any follicular fluid and large atretic follicles did not incorporate any tracer. In medium-sized follicles, accumulation was found in the transitional zone between theca and granulosa cells by $2 \mathrm{hr}$ after the injection, around the granulosa cells between 6 to $24 \mathrm{hr}$, and after this time in follicular fluid. There was no increase in uptake in follicles that were immediately preovulatory. General agreement was expressed that the ${ }^{35} \mathrm{~S}$ was incorporated initially into some of the metachromatic tissues and then moved from the granulosa cells to the fluid. 
There appear to be two different types of mucopolysaccharides in the fluid, which could explain the localization of ${ }^{35} \mathrm{~S}$. One is more viscous, contains hyaluronic acid, and is found in the intercellular substance of the granulosa; the other is less viscous, rich in chondriotin sulphuric acid and is found in the follicular fluid (Zachariae, 1957). Small follicles contained $60 \%$ of the mucopolysaccharide rich in chondroitin sulphuric acid and $40 \%$ of the type with hyaluronic acid, whereas in large follicles the former became much more plentiful (Jensen \& Zachariae, 1958). The fluid lining the cellular layers of the follicles was more gel-like and was largely composed of hyaluronic acid, whereas that in the interior of the follicle had a lower viscosity. Changes in the viscosity of fluid occurred towards ovulation as the mucopolysaccharides were depolymerized. Similar changes could be induced in fluids of small follicles by mixing with those of rupturing follicles. Identification of the two types of mucopolysaccharides may explain the nature of the 'thick' follicular fluid associated with the egg mass at ovulation, as compared with the 'thin' follicular fluid that escapes more freely from the rupturing follicle. The fluid is highly viscous in preovulatory follicles in rhesus monkeys (Koering, 1969; Butler, 1971). Fluid associated with the ovulatory human oocyte is more viscous than that in the antrum of the follicle (Steptoe \& Edwards, 1970), and its high content of hyaluronic acid can be inferred from its rapid dissolution in the presence of spermatozoa. The fluid is more viscous and metachromatic in growing than in fully-grown preovulatory follicles of hamsters and mice (Byskov, 1969; Norman \& Greenwald, 1972).

\section{Proteins}

Analysis of the proteins in follicular fluid has provided much of the evidence revealing its partial equilibrium with serum. Most of the plasma proteins are present in follicular fluid, although there are differences in levels from those in serum and plasma. In this section, we will deal first with the concentration of protein in follicular fluid, and then discuss the levels of particular proteins in it.

Protein concentration. Most estimates agree that the concentration of protein is lower in follicular fluid than in serum. Measurements have been made using biuret and Lowry tests, and showed that the concentration in human fluid was approximately $50 \%$ of that in serum (Manarang-Pangan \& Menge, 1971) (Table 1), 75\% in cow (Caravaglios \& Cilotti, 1957; Desjardin, Kirton \& Hafs, 1966; Pascu, Tudorascu, Stancioiu \& Lunca, 1971), and 60\% in pig (Shivers, Metz \& Lutwak-Mann, 1964; McGaughey \& Daniel, 1972). The protein concentration in human follicular fluid has recently been estimated as similar to that in serum (Shalgi et al., 1972b). The partition of proteins between serum

\section{EXPLANATION OF PLATE 1}

FIg, 1. Ultrastructure of rat ovarian follicles. (a) Primordial follicle showing the basement membrane (arrowed). The spaces indicate the site of formation of the zona pellucida, and there is no follicular fluid. The granulosa cells are undeveloped and single layered, and the thecal cells are also relatively undeveloped. (b) A fully developed Graafian follicle. The antrum is fully formed, the intracellular spaces are filled with follicular fluid, which extends almost to the basement membrane. The thecal layer and the granulosa cells are well developed. Nu : nucleus; M : mitochondria; Ly: lysosome; arrows : site of basal lamina. Illustrations by kindness of Dr P. R. Crombie. 

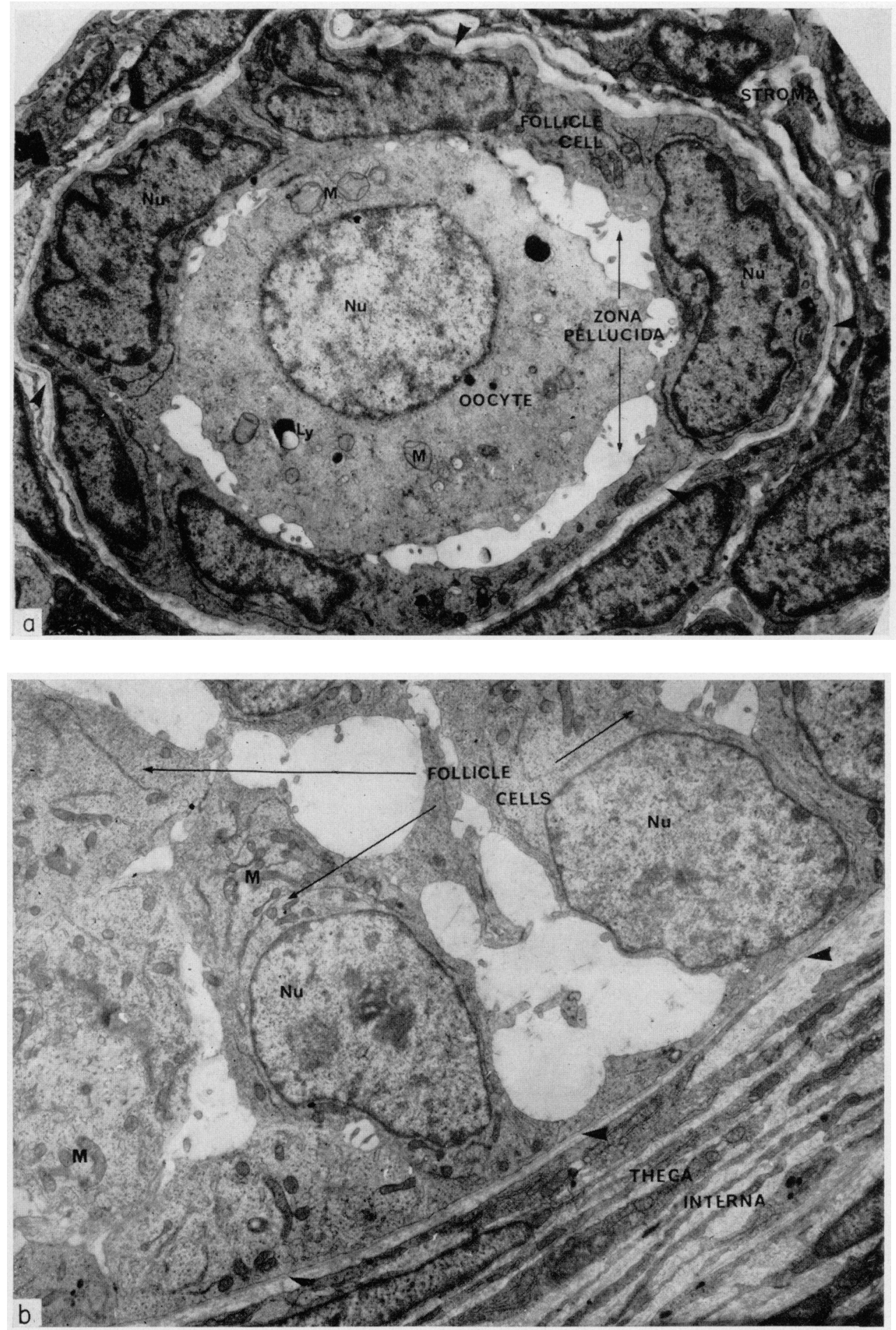

(Facing p. 194) 
PLATE 2

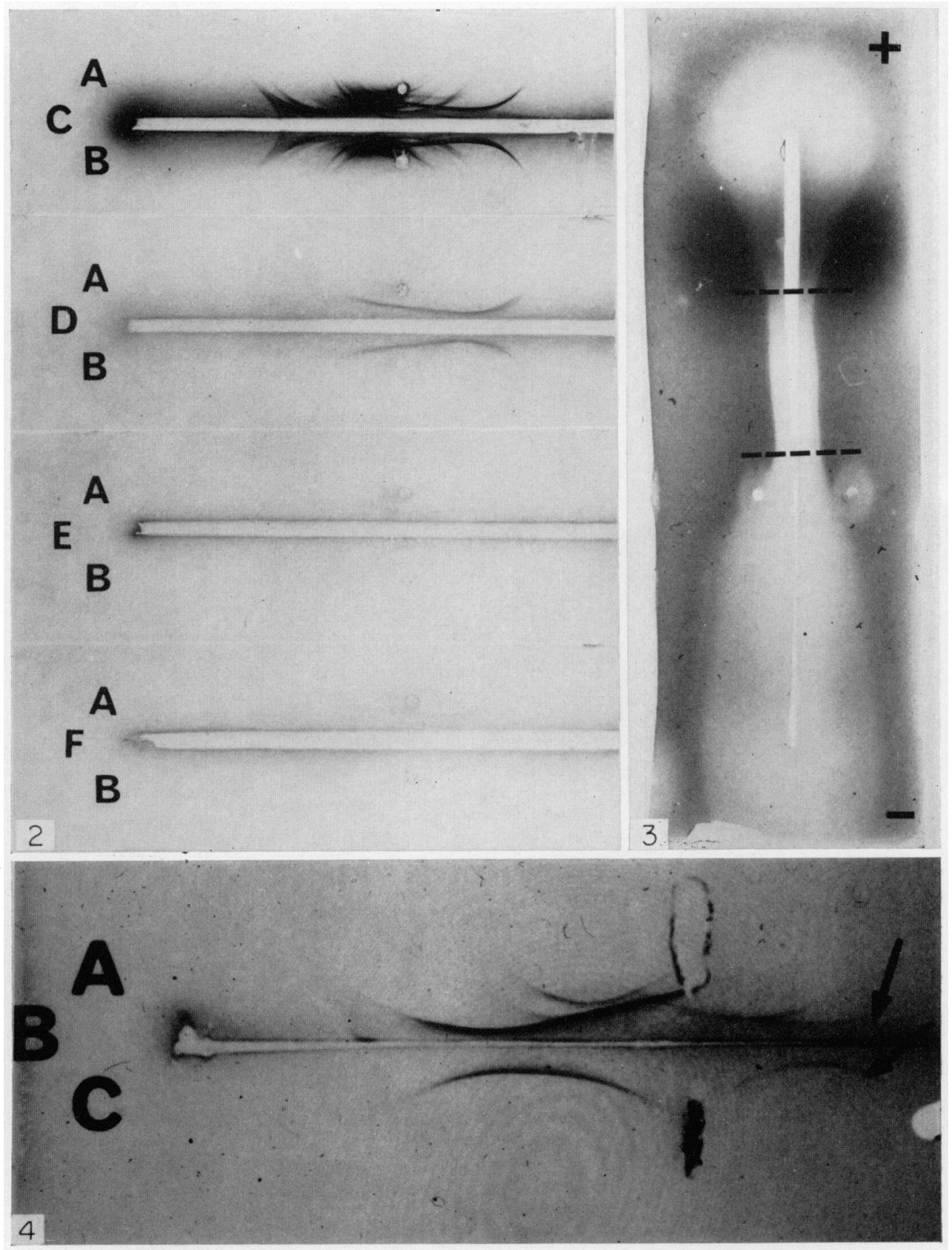

(Facing p. 195) 
and follicular fluid is achieved quickly. Serum proteins labelled with fluorescent dyes were injected intravenously into rats and identified histochemically in follicular fluids within a few hours; unlike in other tissues, the proteins were not concentrated on the basement membrane of the follicle (Mancini and his colleagues, 1961, 1962). Serum proteins with faster rates of decay were transmitted into follicles at higher rates than other proteins, entering the fluid by way of the thecal arteries, granulosa layer and antrum, to be finally localized and retained in all follicular structures and in the oocyte (Mancini, Vilar, Heinrich, Davidson \& Alvarez, 1963). The basement membrane of the granulosa layer of the follicle, and especially of growing follicles, appears to be very permeable, so that penetration occurs between the cells rather than by active transport involving follicular cells. The increased permeability found in growing follicles seems to conflict with observations by Zachariae (1958), for direct observation on follicles of rabbits injected intravenously with Evans blue, which forms complexes with plasma proteins, showed that the dye accumulated in the fluid within 5 min of the injection, entry being gained more quickly into preovulatory follicles than into non-ovulatory follicles. Labelled albumin has also been found to enter the follicle and become localized in the oocyte (Glass, 1971).

Biochemical measurements have also revealed how rapidly plasma proteins enter follicular fluid. Women were given intravenous injections of various compounds, including labelled $\gamma$-globulins, which entered follicular fluid within 6 min (von Kaulla et al., 1958). Various proteins, including whole serum and labelled amino acids, injected intracardially into rats, appeared within $4 \mathrm{hr}$ in fluids aspirated from ovarian cysts induced by gonadotrophins, and persisted longer in these fluids than in serum (Yatvin \& Leathem, 1964) (Text-fig. 1). The major portion of the cystic fluid appeared to be a transudate of plasma.

Plasma proteins. The spectra of proteins in plasma and follicular fluid are very similar, as judged by immunoelectrophoresis, disc-gel electrophoresis and other techniques. The considerable degree of similarity between the fluids has been found using antibodies made against follicular fluid or against serum, most of the antigens being common to both, with the occasional exception of the $\beta$-lipoproteins and fibrinogen (Caravaglios \& Cilotti, 1957; Zachariae \& Jensen,

\section{EXPLANATION OF PLATE 2}

FIG. 2. Immunoelectrophoresis of human serum and follicular fluid. Top: serum (A) and follicular fluid (B), using an antibody against serum (C). Notice the similarity of the components, with the exception of IgM which is relatively deficient in follicular fluid. Lower: monospecific antibodies for human IgG (D), IgA (E) and IgM (F) have been used. Notice that IgG and IgA are found in follicular fluid, but IgM does not give a precipitation line (Johnson, 1973).

FIG. 3. Demonstration of proteinase inhibitor(s) in human follicular fluid, using the method described by Heimburger, Haupt \& Schwick (1971). After electrophoresis of small samples of the fluid in fibrin/agar gel, the centre slot is filled with $\alpha_{1}$-trypsin and the clear areas reveal the lytic activity of the enzyme. In the region indicated, the activity has been suppressed by an inhibitor in follicular fluid (M. H. Surani \& R. G. Edwards, unpublished).

Fig. 4. Immunoelectrophoresis of hamster serum (A) and an ovulated cumulus mass from the hamster oviduct $(\mathrm{C})$, using an antibody against hamster serum (B). Notice that sufficient protein, including $\gamma$-globulin (arrowed) and albumin has migrated from the cumulus mass to give a precipitation band (Johnson, 1973). 
1958; Shivers et al., 1964; Desjardin et al., 1966; Edwards, 1969; ManarangPangan \& Menge, 1971; Beck \& Shelden, 1972; Shalgi et al., 1972b) (Pl. 2, Fig. 2). The oestrogen-binding proteins have been found in follicular fluid (Takikawa \& Yoshinaga, 1968). Occasional claims have been made (e.g. Herve, Sergent \& Robey, 1968) that specific antigens are found in follicular fluids, but they have not been confirmed in later studies (Manarang-Pangan \& Menge, 1971). Nevertheless, some electrophoretic and sedimentation methods have detected differences between the two fluids (Takikawa, 1966), and recent studies using gel-filtration in Sephadex have revealed a component unique to the fluids of small and large pig follicles, as shown by a distinct shoulder on one of the trailing edges of a peak, and another in large follicles only (McGaughey \& Daniel, 1972). It is perhaps surprising that more differences have not been detected by these methods, because there are obviously components unique to follicular fluid as judged by other tests.

Species differences exist in the tendency of follicular fluids to clot. General experience has shown that fluids of preovulatory cow and pig follicles clot easily, whereas those from human follicles do not. Yet fibrinogen is seemingly present in the fluid of many species. An anticoagulant has been postulated to exist in follicular fluid (Palla, 1950).

Differential transmission of protein into follicular fluid. The molecular size, and perhaps the shape, of the molecules influence their transmission into follicular fluid. Biochemical studies showed that the concentration of some proteins, e.g. $\beta_{2}$-globulins, was similar in bovine follicular fluid and plasma (Zachariae \& Jensen, 1958), whereas others were lower in the fluid, e.g. albumin, $\alpha$-globulins

Table 4. Proteins in human follicular fluid and serum (mg \%) (from Johnson, 1973)

\begin{tabular}{l|c|c|c}
\hline & $\begin{array}{c}\text { Follicular } \\
\text { fluid }\end{array}$ & Serum & $\%$ serum \\
\hline Albumin & 2560 & 4400 & 58 \\
$\alpha_{1}$-glycoprotein & 45 & 90 & 50 \\
IgG & 580 & 1300 & 45 \\
$\beta_{1}$ A-globulin & 45 & 100 & 45 \\
Transferrin & 149 & 320 & 41 \\
Haptoglobin & 65 & 160 & 41 \\
IgA & 75 & 210 & 36 \\
IgM & 17 & 140 & 12 \\
$\alpha 2$-macroglobulin & 28 & 240 & 12 \\
\hline
\end{tabular}

(Zachariae \& Jensen, 1958) and $\gamma$-globulins (Takikawa, 1966). Contrasting results for albumin and $\beta$-globulins showed them to be present in higher concentrations in the fluid (Caravaglios \& Cilotti, 1957; Takikawa, 1966; Pascu et al., 1971). The analysis of cellulose acetate electropherograms of pig follicular fluid and serum showed that albumin levels were higher in the fluid, although levels of macroglobulins were lower (McGaughey \& Daniel, 1972). Radial immunodiffusion has been used to assay the concentration of various proteins in aspirates of human follicular fluid (Table 4) (Johnson, 1973). The relative concentrations in the fluid depended on the molecular size of the protein, the amount decreasing 
as molecular size increased: the immunoglobulins provide a good example. The same method showed that human follicular fluids contained approximately $40 \%$ of the fibrinogen present in serum and no $\beta_{1}$-lipoproteins (Shalgi et al., 1972b).

This evidence shows clearly that many components of follicular fluid are in equilibrium with levels in serum. The fluid is obviously accessible to almost any component present in the circulation, a situation in the reproductive tract that is almost unique to the follicle. Large molecules are evidently found in low concentrations in other parts of the male and female genital tracts. Agents capable of interfering with the development of the oocyte could be introduced through the follicle, and could also exert their effects after ovulation, for there are relatively large quantities of follicular fluid between the cumulus cells. Thus, agents such as plasma antibodies against spermatozoa (Hansen \& Hjort, 1971; Hansen, 1972) could interfere with fertilization. Not surprisingly, evidence of antibody activity has been found within follicular fluids. Human blood group antibodies were detected by Heglar (1962), and antibodies against semen were found in follicular fluid of immunized heifers (Menge, 1970).

Proteins synthesized within the follicle. A wide range of enzymes are found within follicular fluid (Lutwak-Mann, 1954), their concentrations increasing as the follicle grows. Many of these enzymes are common to other tissues, and they presumably do not have a rôle specific to the follicle. Various enzymes, including ATPase, lactate dehydrogenase, transaminases and alkaline phosphatases were identified in follicular and cyst fluid from human ovaries (Cerletti \& Zichella, 1961 ; Caucig, Friedrich, Hager \& Golob, 1971), and acid and alkaline phosphatases, various isomers of lactate dehydrogenase and other enzymes in bovine follicular fluid (Stallcup, 1970). Many of the enzymes in the fluid are evidently concerned with catabolic transformations of compounds originating in the wall of the follicle (Cerletti \& Zichella, 1961). The distribution of enzymes in the wall and fluid of follicles of various species, together with an analysis of their contribution to follicular rupture, was described by Wegmann \& Hadjiisky (1969). The significance to ovulation of enzymes involved in intermediary metabolism remains to be proven; lysosomal enzymes could obviously play a rôle in follicular rupture. Esterases and other enzymes are present in and between cells of the membrana granulosa, especially in atretic follicles (Hunter \& Kneiske, 1957; Jung \& Held, 1959; Deane, 1952; Bulmer, 1965; Holzinger, 1972).

Various enzymes believed to be specifically concerned with follicular rupture have been reported or postulated to exist in the follicular tissues and fluids. These include hyaluronidase (Zachariae \& Jensen, 1958), endopeptidase (Jung, 1965), and a collagenase (Rondell, 1970). Most attention has recently been given to the collagenase, although its substrate specificity was maximal for an artificial polymer rather than for collagen; the enzyme could increase the distensibility of the stigma by digesting its collagen substrate. This enzyme can be found in the fluid of preovulatory follicles, although its preferential location appears to be on the outside of the follicle, where it 'weeps' over the surface just before ovulation (Rondell, 1970).

In general, the search for proteins specific to the follicular fluid using immunoelectrophoresis and most biochemical methods has been unrewarding. Some 
indications of specific proteins in the fluid have come from sedimentation and gel-filtration methods, as described above (p. 195).

\section{GONADOTROPHINS AND STEROID HORMONES IN FOLLICULAR FLUID}

\section{Gonadotrophins}

Gonadotrophins obviously play an important rôle in the growth and development of the follicle. Some observations indicate that their action is exerted from the earliest stages of development, for antisera against gonadotrophins can suppress the growth of primary follicles in prenatal rats (Eshkol, Lunenfeld \& Peters, 1970). This evidence seems to conflict with observations that follicular growth continues after hypophysectomy (Ben-Or, 1963), for the source of gonadotrophins should be removed by this procedure. The rôle of the two gonadotrophins in the growth of the follicle has been reviewed extensively (Brambell, 1960; Young, 1961). Recently FSH has been apportioned a rôle in follicular cell proliferation and the development of the basement membrane, while FSH and LH together induce the formation of the antrum, enrichment of the theca and development of the vasculature (Eshkol et al., 1970).

The numbers of gonadotrophin-binding sites change in quantity and quality as the follicle grows. A fifteenfold increase in quantity has been found as pig follicles enlarge as judged by the binding of ${ }^{125}$ I-HCG (Channing, 1972). The gonadotrophins evidently bind to the theca interna and basal layers of the granulosa (Rajaniemi \& Vanha-Pertulla, 1972). Activity due to LH or HCG at levels of $<40$ to $200 \mathrm{mU} / \mathrm{ml}$ was detected in the fluid of human follicles primed with exogenous gonadotrophins (G. E. Abraham, R. G. Edwards, P. C. Steptoe and J. M. Purdy, unpublished data), which is higher than levels generally found in plasma. Unfortunately, samples of plasma were not available for comparison. Concentrations of LH in the fluid of sheep follicles were $>75 \mathrm{ng} / \mathrm{ml}$, which was much higher than in plasma (Bjersing and his colleagues, 1972). Changes in the nature of the binding sites for gonadotrophins were reported by J. L. Popova (personal communication), at approximately the time that LH would have stimulated the preovulatory changes in the follicle.

The theca interna has been shown to bind FSH (Greep, 1973). No studies have been reported on the identification of this hormone in follicular fluid, but it must presumably be present in Graafian follicles of most species. The hormone did not bind to the thecal cells of small follicles, which indicate that the binding sites must differentiate as follicles grow.

Measurements of the synthesis of cyclic AMP have shown that it rises initially and then declines abruptly in follicles approaching ovulation following gonadotrophin stimulus (Marsh, Mills \& Le Maire, 1972, 1973). The cause of this rapid decline is not understood but it seems to imply that gonadotrophins are no longer being utilized by the follicles at this time.

\section{Steroids}

The synthesis of steroids by the ovary has been reviewed extensively (e.g. Sommerville, 1969; McKerns, 1969). Follicular fluid has for many years been known to contain steroids, especially oestrogen since the work of Allen, Doisy, 


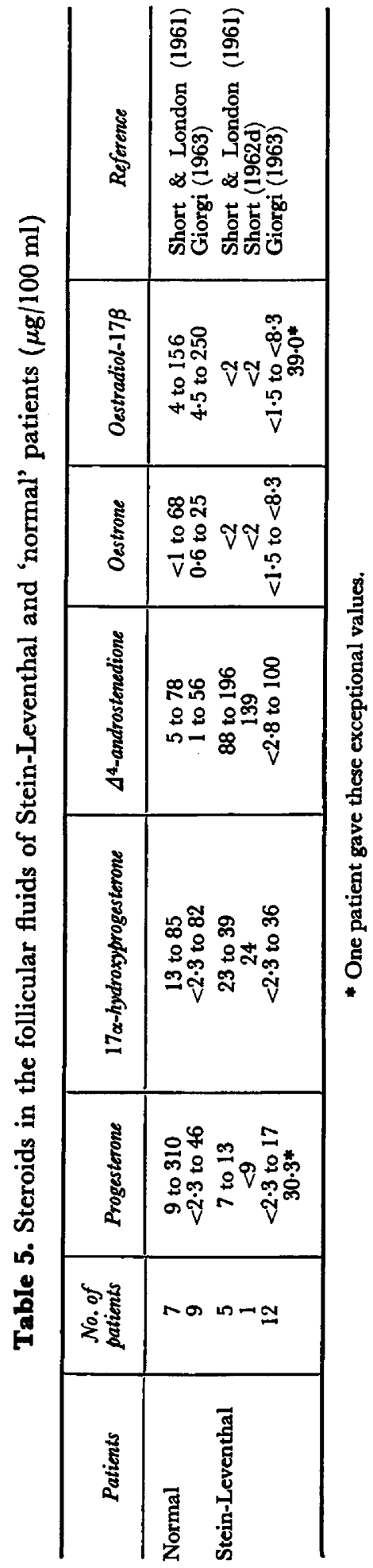


Edgar and others (Parkes, 1929). Detailed studies on the nature of the steroids and their turnover rates have been more recent as analytical methods have been improved, and as the relative steroidogenic activity of the theca interna and membrana granulosa has been recognized. Much of this work involves tissue culture, and problems of interpretation could arise with this method because granulosa cells luteinize spontaneously in culture (Channing, 1970). Assays of steroids in follicular fluids are currently being used to examine the growth of follicles during natural and induced cycles.

A wide variety of steroids including oestrogens, androgens and progestagens has been identified in follicular fluid (e.g. Short, 1964a, b). In the mare, for example, nine were identified in fluids collected during the oestrous and luteal stages of the cycle (Short, 1960a, b, 1961a, b, 1962b). Oestradiol-17 $\beta$ was found to be the dominant steroid in most of the samples, and progesterone and $20 \beta$ hydroxy-pregn-4-en-3-one in one of them which was collected from a pregnant female. The ratios of some steroids in the fluid differed from those in blood, e.g. the fluid was relatively richer in androstenedione. Eight steroids were present in detectable amounts in bovine follicular fluid, oestradiol-17 $\beta$ being present in the highest concentration; concentrations of steroids varied greatly in different cysts, levels of progesterone being slightly greater than those of oestradiol (Short, 1962a, c).

Pooled samples of human follicular fluid were assayed initially (e.g. Smith, 1960), but steroids have now been measured in individual fluids. Oestrogens and progestagens are found in fluids taken from women with a normal menstrual cycle (Table 5), but wide variations occur in certain clinical conditions. High levels of androstenedione and almost no oestrogens were present in fluids from patients with the Stein-Leventhal syndrome, probably due to the lack of 19hydroxylase activity in these patients (Short \& London, 1961; Short, 1962d; Giorgi, 1963) (Table 5). Levels of progesterone in follicular fluid during the follicular phase were higher in patients with functional uterine bleeding than in those with a normal cycle (Giorgi, 1965). Free and conjugated oestrogens were identified in human fluid, more free oestrogens being found during the follicular phase and in follicular cysts, and levels of both being similar in cystic corpora lutea and polycystic ovaries (Giorgi, 1967). Simplified methods of radioimmunoassay for oestradiol-17 $\beta$, avoiding extraction and chromatography, were effective with human follicular fluid because of its high content of unconjugated oestrogens (Abraham, Odell, Edwards \& Purdy, 1970). Species differences in the content of steroids in follicular fluids include, for example, the occasional detection of testosterone in bovine fluids but not in those of the mare or human, and of epi-testosterone in equine but not in bovine fluid (Short, 1962a, b).

The steroidal content of follicular fluid varies according to the stage of development of the follicle. More steroids, especially oestrogen, are found in the fluid of enlarging follicles. Levels then decline, abruptly as the follicle becomes preovulatory, or more gradually as the follicle becomes cystic. Concentrations vary widely, however, between different follicles in the same animal or between animals. Thus, differences between steroid levels in the follicular and luteal phases in equine and bovine follicles are not clear-cut (Short, 1961a, 1962c; Lunaas, 1964). Raised levels of oestrogen and progesterone are found during 


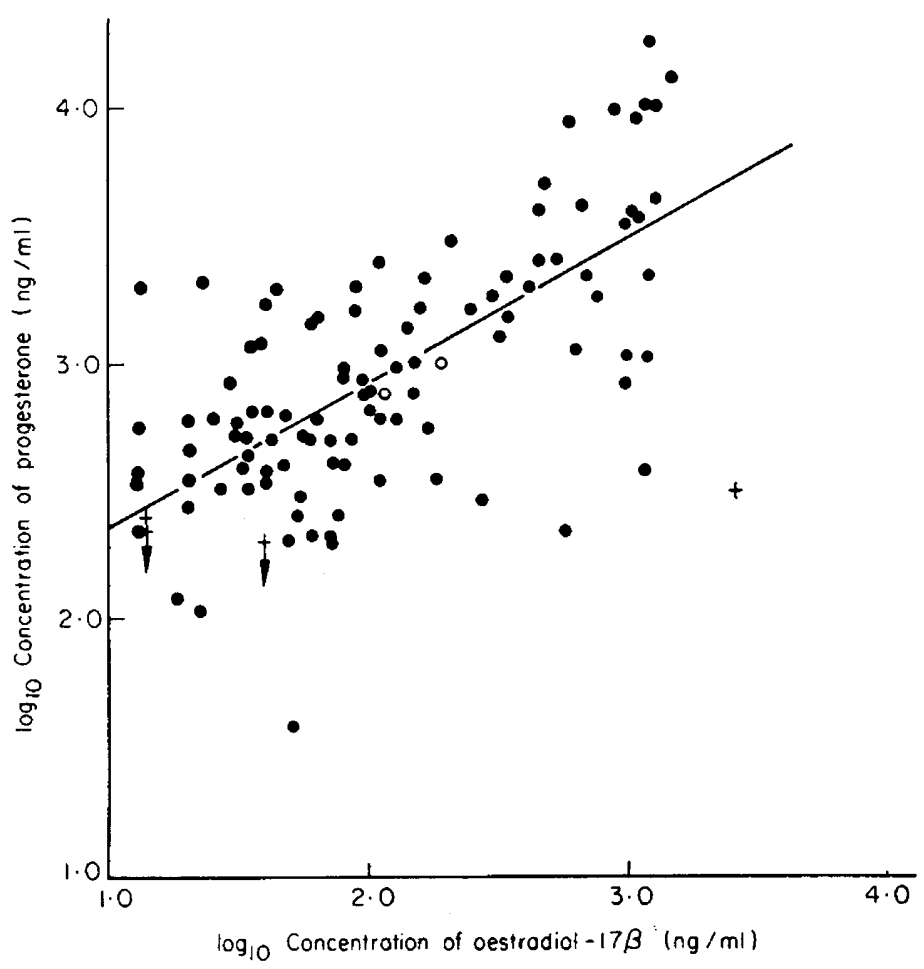

TEXT-FIG. 2. Levels of oestradiol-17 $\beta$ and progesterone in fluid aspirated from human follicles. 9 , Follicles primed with exogenous gonadotrophins; $O$, follicles on Day 13 of a patient with 28-day menstrual cycles; + , follicles on Day 12 of a patient with 35-day menstrual cycles. Most of the fluids were collected just before the expected time of ovulation from ovaries primed with gonadotrophins, and others during the natural cycle. From Edwards et al. (1972), by courtesy of the Lancet.

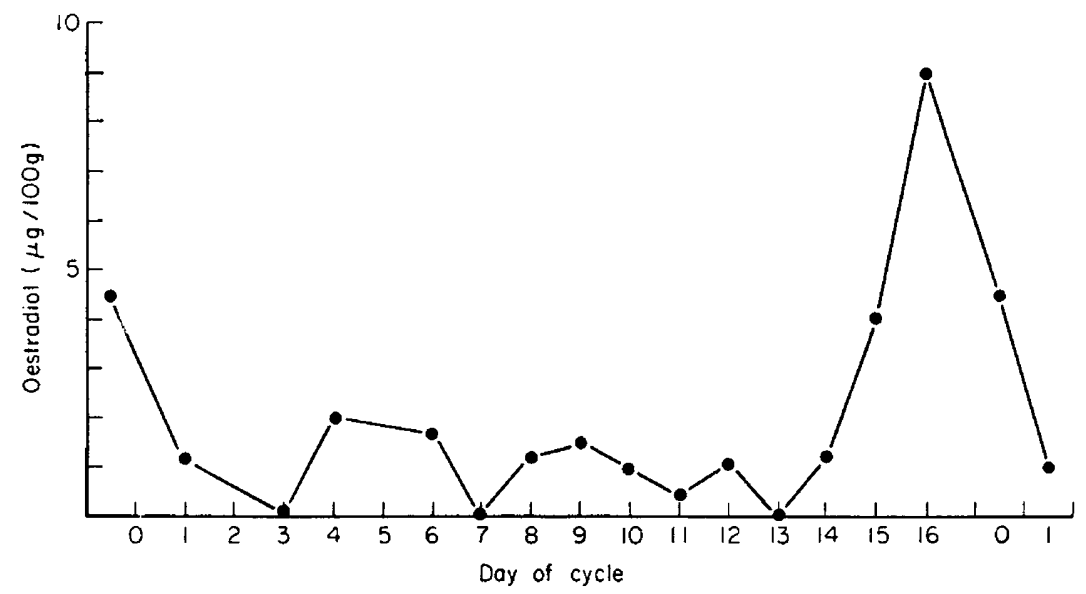

TEXT-FIG. 3. Oestradiol-17 $\beta$ in follicular fluid of the sheep during the oestrous cycle (from Brand, 1970). 
vascularization of the equine follicle (Short, 1964a; YoungLai, 1971; Bjersing \& YoungLai, 1972). In human follicular fluid, free oestrogens are more plentiful in fluids during the follicular phase than during the luteal phase, and conjugated oestrogens showed a similar variation (Giorgi, 1967); levels of oestradiol-17 $\beta$ and progesterone were higher close to the mid-point of the cycle (Edwards and his colleagues, 1972; Sanyal, Nudemberg, Berger \& Taymor, 1972) (Text-fig. 2). The relationship between ovine follicular development and steroids in fluids is shown by assays of oestradiol-1 $7 \beta$; levels in fluid were sixty times greater than in serum, and fluctuations typical of the stage of follicular growth occurred in both fluids (Brand, 1970) (Text-fig. 3). This approach could help in the analysis of the successive waves of follicular development within a single cycle (Brand, 1970).

Concentrations of steroids in rabbit follicular fluids decline abruptly just before ovulation, as shown by assays for oestrogen and 'progestin' (YoungLai, $1972 \mathrm{~b}$ ). The changes were remarkable - initially, the induction of preovulatory growth in follicles resulted in a transient increase in steroid concentrations, to be succeeded within $2 \mathrm{hr}$ by a decline to almost zero. The changes seemed to be determined by a distinct alteration in steroidogenesis by the follicles, for plasma hormone levels also declined during this period although not as precipitously (Hilliard \& Eaton, 1971). Similar phenomena probably occur in equine follicles (Short, 1964a) and in those of the sheep and monkey, wherein plasma levels of oestradiol decline while the preovulatory follicle is still intact (Moore and his co-authors, 1969; Bjersing et al., 1972; Knobil, 1972). This point will be raised below in discussion of the preovulatory changes in follicles. Equine Graafian follicles undergoing atresia also contain low quantities of steroids (Short, 1964a). Follicular fluid is obviously a repository for many of the steroids produced by the theca and granulosa cells, and reflects their changing patterns of synthesis. Evidently it does not contribute to cellular metabolism in any chemical or physical manner, for aspirated follicles continue to produce steroids (Short, 1964a).

Samples of human follicular fluid taken from patients treated with gonadotrophins have been analysed. Progesterone was the most plentiful steroid during the treatment of patients with the Stein-Leventhal syndrome, the situation reverting 36 days later to the excess of androstenedione normally found in these women (Crooke, 1969). Oestradiol-17 $\beta$ and progesterone were assayed in fluid collected from more than 100 human follicles just before ovulation was expected in patients given gonadotrophins (Abraham et al., 1970; Edwards et al., 1972). Two types of Graafian follicle were present in the ovaries, one being immediately preovulatory and the other non-ovulatory. Levels of oestradiol and progesterone varied greatly in different follicles, from $<12.5$ to $1700 \mathrm{ng} / \mathrm{ml}$ and from 65 to $18,000 \mathrm{ng} / \mathrm{ml}$ respectively (Text-fig. 2). The correlation between the two hormones was:

$$
\mathrm{E}_{2}=37 \cdot 44+0 \cdot 178 \mathrm{P}-\left(6 \cdot 195 \times 10^{-6}\right) \mathbf{P}^{2}
$$

where $E_{2}$ is the concentration of oestradiol $(\mathrm{ng} / \mathrm{ml})$ and $P$ the concentration of progesterone; the linear and quadratic coefficients were both significant, showing that progesterone was accumulating slightly faster. No relationship between steroid levels and follicular size was apparent, although variations were greatest 
in preovulatory follicles. The low levels of steroid in some of the preovulatory follicles is perhaps best explained from evidence in animals showing that they become inactive in steroidogenesis just before ovulation.

\section{Metabolic pathways during steroidogenesis in follicles}

The nature of the steroids identified in follicular fluids, together with conversion studies using follicular cells or intact follicles have provided data on metabolic pathways during steroidogenesis. Thecal and granulosa cells differ in their transformations. In various species, granulosa cells are more active in $3 \beta$-hydroxysteroid dehydrogenase activity, and so efficiently convert pregnenolone to progesterone, whereas thecal cells have a more effective desmolase and aromatizing activity in vivo for further conversions, especially to oestrogens (Short, 1962b, 1964a; Bjersing \& Carstensen, 1964; Ryan \& Petro, 1966; Ryan, Petro \& Kaiser, 1968; YoungLai, Edwards \& Steptoe, 1972). Aromatizing activity has been recorded in cultured granulosa cells (Bjersing \& Carstensen, 1964; Ryan \& Short, 1965; Channing, 1969), although the spontaneous luteinization of granulosa cells in vitro may have activated the enzyme systems.

Analyses on the metabolism of the follicle in vivo avoid many of the problems associated with tissue culture. Information on conversions in vivo and on the rate of transfer of steroids from the follicle to the blood were obtained in mares by instilling radioactive precursors into Graafian follicles and then collecting ovarian vein blood and follicular fluid 40 to 50 min later (Short, 1964a; YoungLai \& Short, 1970). Between 6 and $12 \%$ of the pregnenolone in follicular fluid was converted to progesterone in under an hour, but further conversion to $17 \alpha$-hydroxyprogesterone was slight. The authors imply that progesterone in follicular fluid may be derived from the thecal cells, the low levels of this steroid in follicular fluid being due to precursor starvation of the granulosa. Oestradiol$17 \beta$ too was evidently synthesized in the theca interna, and then diffused into follicular fluid. Steroids diffuse slowly from the follicle into the circulation, approximately $5 \%$ of the pregnenolone and androstenedione in the fluid being transferred to the ovarian vein each hour. Free and conjugated oestrogens are also retained in equine follicular fluid, perhaps because they are bound to globulins; transmission from the follicle was much greater in the presence of albumin (Giorgi, Addis \& Colombo, 1969). This retention in fluid is similar to that found with various labelled proteins as described above.

Recent studies in several species have shown that the granulosa cells may become active in steroid synthesis before ovulation. Levels of $3 \beta$-hydroxysteroid dehydrogenase in hamster cells rise as the follicle approaches ovulation, as judged by histochemical tests (Wingate, 1970; Blaha \& Leavitt, 1971; Norman \& Greenwald, 1972). Progesterone synthesis by the follicle increases at this time (Norman \& Greenwald, 1971). Fluids from highly vascularized follicles of the mare contained large amounts of oestrogen and detectable amounts of progestin as judged by several methods; the granulosa cells, but not the thecal cells, from oestrous follicles were again found in biochemical tests to possess active $\Delta^{5}-3 \beta$ hydroxysteroid dehydrogenase activity (YoungLai, 1971). The agranular endoplasmic reticulum of the granulosa cells was more highly developed in the mare than in other species (Bjersing \& YoungLai, 1972). 
Table 6. Conversion of pregnenolone to progesterone by granulosa cells aspirated from human follicles shortly before the expected time of ovulation (YoungLai et al., 1972)

\begin{tabular}{c|c|c|c}
\hline $\begin{array}{c}\text { Follicle } \\
\text { no. }\end{array}$ & $\begin{array}{c}\text { Approximate } \\
\text { size }(\mathrm{cm})\end{array}$ & $\begin{array}{c}\text { Stage of } \\
\text { development } \\
\text { of follicle }\end{array}$ & $\begin{array}{c}\text { \% conversion } \\
\text { of pregnenolone } \\
\text { to progesterone }\end{array}$ \\
\hline 1 & 1 & Not known & $45 \cdot 4$ \\
2 & 3 & Ovulatory & $25 \cdot 8$ \\
3 & $0 \cdot 5$ & Ovulatory & $9 \cdot 9$ \\
4 & 2 & Not known & $17 \cdot 8$ \\
5 & $2 \cdot 5$ & Not known & $16 \cdot 4$ \\
6 & 2 & Not known & $22 \cdot 1$ \\
7 & 1 & Non-ovulatory & $41 \cdot 4$ \\
8 & 1 & Non-ovulatory & $44 \cdot 2$ \\
\hline
\end{tabular}

Human granulosa cells from non-ovulatory and pre-ovulatory Graafian follicles could transform pregnenolone to progesterone (YoungLai et al., 1972) (Table 6), although differences in the rate of conversion remain to be quantified.

FOLLICULAR FLUIDS AND THE GROWTH, MATURATION AND

RUPTURE OF THE FOLLICLE

\section{Growth of the follicle}

Certain biochemical parameters in follicular fluid indicate the stage of development of a follicle. Lowered levels of vitamin $\mathrm{D}$, for example, have been associated with atresia (Pascu et al., 1970), and various degrading enzymes are found in the tissues and fluids of atretic follicles (see p. 197). The clearest levels of follicular maturation arise from assays of the types of steroids present in follicular fluid (p. 198). Some caution is necessary in interpreting these kinds of data, for steroids are transmitted at different rates from the follicle (Short, 1964a). Levels of oestrogen in fluid rise as follicles grow, and progesterone levels increase close to ovulation. Low levels of steroids, with a high ratio of progesterone, indicate the formation of a cyst.

The pattern of steroidogenesis, and the duration of life of the follicle and corpus luteum might be 'built-in' to the follicle at least in some species, as shown for example by evidence in the changing steroid levels in the fluid of sheep follicles in vivo (Text-fig. 3) and by the continued development of cultured follicles for some time along the pattern expected in vivo (Brand, 1970; Moore, Hay \& Caldwell, 1971). In primates, the life-span of the follicle appears to be determined autonomously, even to the synthesis of oestrogens invoking the release of LH from the pituitary; the innate life-span of the corpus luteum determines the length of the luteal stage, provided that small supporting doses of gonadotrophins are available (Vande Wiele and his colleagues, 1970; Knobil, 1972). Analyses of the growth and differentiation of follicles and of follicular dynamics would be helped considerably if measurable by the hormonal assay of their fluid. The assay of steroids in follicular fluid or of those released in culture could thus provide indications of ovarian dynamics, including the waves of follicular growth known to occur in the cycle. 
The synthesis of particular steroids by follicles or corpora lutea can influence the growth of neighbouring follicles as shown recently in sheep, where more follicles were found in the ovary containing a corpus luteum (Dufour, Gunther \& Casida, 1972).

\section{Oocyte maturation and luteinization of the follicle}

Oocyte maturation and luteinization are initiated by the LH surge, but the actual mechanisms involved in the follicle remain obscure. The oocyte may exert some inhibitory effects on luteinization (Young, 1961; El-Fouly, Cook, Nekola \& Nalbandov, 1970; Nekola \& Nalbandov, 1971). A 'meiogenic function' is postulated for follicular fluid (Moricard, 1967, 1968, 1969); this property will presumably change as the fluid alters in composition during growth of the follicle. Conflicting reports on the effect of follicular fluid on granulosa cells include suggestions that it contains a substance inhibiting the luteinization of pig granulosa cells (Nalbandov, 1972), yet it stimulates growth and steroidogenesis by granulosa cells (Bradbury, 1961; YoungLai, 1972a). The rôle of follicular fluid in these events requires further analysis, and some information can be gleaned by culturing follicles in vitro, or by injecting compounds into the antrum. Neither oocyte maturation nor luteinization occurs in intact follicles maintained in a simple medium, but the addition of LH can invoke both (Edwards, 1962; Keyes, 1969; Ellsworth \& Armstrong, 1971; Baker, 1972; Tsafriri, Lindner, Zor \& Lamprecht, 1972). Local effects occur in the ovary, as shown experimentally by the induction of luteinization in particular rabbit follicles by intraluminal injections of gonadotrophins (Jones \& Nalbandov, 1972).

Similar types of study are beginning to reveal the importance of protein synthesis, prostaglandins and cyclic AMP and its derivatives in follicular cells and fluid during maturation and luteinization. Prostaglandin levels appear to rise during oocyte maturation, as judged by assays of $\mathrm{PGE}_{2}$ and $\mathrm{PGF}_{2_{\alpha}}$ in intact rabbit follicles (Le Maire and his co-authors, 1973), and intrafollicular injection

Table 7. Endocrine and metabolic activity of the rabbit follicle between stimulation by $\mathrm{LH}$ and ovulation

\begin{tabular}{|c|c|c|c|c|c|}
\hline \multirow{2}{*}{$\begin{array}{c}\text { Time } \\
\text { after LH } \\
\quad(h r)\end{array}$} & \multicolumn{2}{|c|}{$\begin{array}{l}\text { Levels of steroid } \\
\text { in follicular fluid* }\end{array}$} & \multirow{2}{*}{$\begin{array}{l}\text { Proportional } \\
\text { synthesis of } \\
\text { cyclic } A M P \uparrow\end{array}$} & \multicolumn{2}{|c|}{$\begin{array}{l}\% \text { follicles ultimately ovulating } \\
\text { after an injection at this time with: }\end{array}$} \\
\hline & $(p g / m g)$ & $(p g / m g)$ & & Puromycin & Cycloheximidet \\
\hline \multirow{5}{*}{$\begin{array}{l}0 \\
1 \text { to } 2 \\
2 \text { to } 3 \\
3 \text { to } 4 \\
4 \text { to } 5 \\
5 \text { to } 6 \\
9 \\
12\end{array}$} & 60 & 0.75 & 100 & \multirow{5}{*}{$\begin{array}{l}<2 \\
20 \\
40 \\
75 \\
90\end{array}$} & \multirow{5}{*}{$\begin{array}{l}<2 \\
<2 \\
40 \\
75 \\
75\end{array}$} \\
\hline & 271 & 1.53 & & & \\
\hline & & & 10 & & \\
\hline & 30 & $0 \cdot 40$ & & & \\
\hline & $\begin{array}{l}<10 \\
<10\end{array}$ & $\begin{array}{l}<0.20 \\
<0.20\end{array}$ & 10 & & \\
\hline
\end{tabular}

* YoungLai (1972b).

$\dagger$ Modified data of Marsh et al. $(1972,1973)$.

$\ddagger$ Pool \& Lipner (1966). 
of $\mathrm{PGE}_{2}$ will stimulate the maturation of mouse oocytes (Tsafriri et al., 1972). Cyclic AMP is also reported to induce maturation and luteinization (Tsafriri et al., 1972), but other authors have not confirmed this observation (Keyes, Canastar \& Miller, 1972), and others have allocated a suppressive action to this compound (Le Maire, Mills, Ito \& Marsh, 1972). The rôle of cyclic AMP in preovulatory follicles seems to be variable, for its synthesis is considerably stimulated by LH for an hour or so, but then declines to very low levels (Marsh et al., 1972, 1973; Le Maire et al., 1973; and Table 7). This evidence, together with the earlier conclusions that steroid levels in follicular fluid decline to very low levels just before ovulation (Table 7) implies that follicles 'switch off' for a brief period before ovulation, and no longer utilize gonadotrophin. Likewise, hypophysectomy does not suppress the rise in progesterone synthesis in hamster follicles, if it is performed after the initial LH surge has begun (Norman \& Greenwald, 1971), and inhibitors of protein synthesis are effective in suppressing luteinization for only a brief period after the LH surge (Pool \& Lipner, 1966; Keyes et al., 1972) (Tables 7 and 8).

The final stages of preovulatory swelling include physical changes such as an increase in the amount of follicular fluid, dissolution of the basement membrane, sloughing of granulosa cells into the fluid and an increased blood flow in the ovary, due probably to LH (Young, 1961; Wurtman, 1964; Norman \& Greenwald, 1971). Many granulosa cells are seen in aspirates of preovulatory human follicles (Steptoe \& Edwards, 1970). Simultaneous changes also occur

Table 8. Progesterone synthesis by the hamster follicle following hypophysectomy after the onset of the critical period

\begin{tabular}{|c|c|c|c|c|c|}
\hline \multirow{2}{*}{$\begin{array}{l}\text { Time after } \\
\text { critical } \\
\text { period (hr) }\end{array}$} & \multicolumn{2}{|c|}{ Plasma progesterone } & \multicolumn{3}{|c|}{ Ovarian tissue progesterone } \\
\hline & $I$ & III & $I$ & $I I$ & III \\
\hline $\begin{array}{l}3 \\
31\end{array}$ & 9 & 13 & 31 & $1 \cdot 6$ & 33 \\
\hline $7^{2}$ & 11 & 15 & 44 & & 45 \\
\hline
\end{tabular}

I = intact animals. II = hypophysectomized at beginning of the critical period. III = hypophysectomized $3 \mathrm{hr}$ after critical period. Data from Norman \& Greenwald (1971).

in the viscosity and metachromasia of the fluid in mice, hamsters and rabbits, in the last hour or so before rupture of the follicle (Zachariae \& Jensen, 1958; Byskov, 1969; Norman \& Greenwald, 1972). The 'thick' follicular fluid associated with human oocytes probably contains hyaluronic acid, for it is rapidly dissolved by spermatozoa (Steptoe \& Edwards, 1970). Follicular fluid in the rhesus monkey is viscous at ovulation and may be tinged with blood (Koering, 1969; Butler, 1971). A generalized haemorrhagic appearance has been described in some human preovulatory follicles and in those of the macaque monkey (Steptoe \& Edwards, 1970; Jewett \& Dukelow, 1972). Some disagreement exists 
Follicular fuid

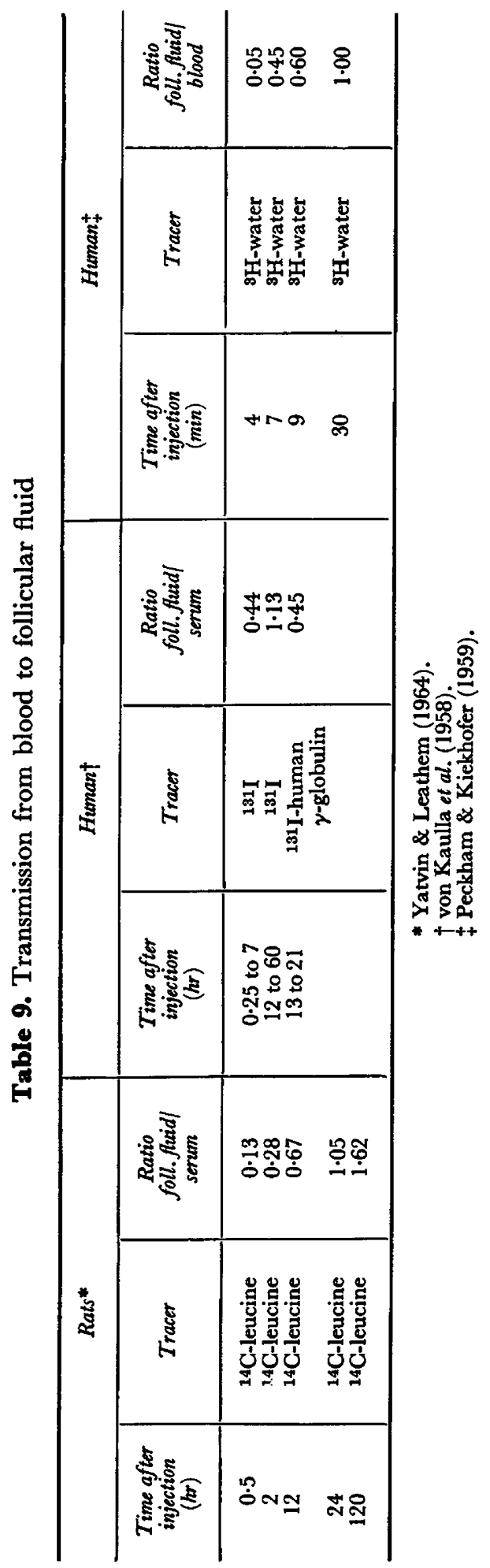


about the nature of the preovulatory changes in the rhesus monkey (Johansson, Neill \& Knobil, 1968; Betteridge, Kelly \& Marston, 1970).

\section{The follicular membrane as a barrier}

Substances are constantly being transmitted across the follicular membrane in both directions. Various labelled precursors, e.g. phosphorus, glycine and sulphate, are located in the fluid of growing follicles shortly after a systemic injection (Odeblad, 1954; Nati \& Odeblad, 1955; Edwards \& Sirlin, 1958). Kinetic studies have not been carried out on the differential rates of the inward or outward flow, and some estimates of the two-way transmission rates are shown in Tables 9 and 10. Entry into the follicle is best measured from the ratio of the amount of the compound present in fluid and blood. Transmission from the follicle can be measured by successive samplings of the fluid. Rates of transmission depend on the size of molecules, and perhaps on their chemical properties. Compounds such as tritiated water are distributed in equal concentrations in fluid and plasma within minutes, whereas some large molecules seem to be permanently in low concentrations in fluid (see p. 194). Such low concentrations must arise through a slow rate of diffusion compared with the increasing volume of fluid. Likewise, plasma oestradiol diffuses slowly into fluid (Braunsberg, Irvine \& James, 1967).

Transfer from fluid to blood is also restricted. Steroids are largely retained in fluid (p. 198), perhaps through binding to globulins, for they are transmitted more readily from equine follicles in the presence of albumin (Giorgi et al., 1969) (Table 10). Exit from the follicle occurs directly through the ovarian vein and

Table 10. Transmission of steroids from the fluid of the equine follicle into circulating blood

\begin{tabular}{l|l|l}
\hline $\begin{array}{c}\text { Time after } \\
\text { injection (min) }\end{array}$ & \multicolumn{1}{|c|}{ Tracer } & \multicolumn{1}{c}{$\begin{array}{c}\text { \% transmitted } \\
\text { from follicle }\end{array}$} \\
\hline \multirow{2}{*}{30} & ${ }^{14} \mathrm{C}$-oestradiol-17 $\beta^{*}$ & 5 \\
45 to 52 & ${ }^{14} \mathrm{C}$-androstenedione and ${ }^{3} \mathrm{H}$-pregnenolone $\dagger$ & $3 \cdot 2$ to $9 \cdot 1$ \\
60 & ${ }^{14} \mathrm{C}-0$-ostradiol-17 $\beta^{*}$ & 23 \\
& ${ }^{3} \mathrm{H}$-oestradiol-17 $\beta$-glucuronide & 45 \\
36 & ${ }^{14} \mathrm{C}$-oestradiol-17 $\beta$ with albumin $\left.{ }^{*}\right)$ & 98 \\
& ${ }^{3} \mathrm{H}$-oestradiol-17 $\beta$-glucuronide with albumin & 99 \\
\hline
\end{tabular}

* Giorgi et al. (1969)

† YoungLai \& Short (1970).

indirectly by way of interstitial fluid and tissue (Lunaas, 1964; Giorgi et al., 1969). Molecular transfer through follicular and thecal cells has been ascribed to active transport, and across the membrane to diffusion (Aratei, 1972). Rates of transmission could alter during preovulatory changes in follicles, as shown by the more rapid entry of dyes into them (Zachariae, 1958).

\section{Rupture of the follicle}

The hypotheses offered to explain follicular rupture have been frequently reviewed (Odeblad, 1954; Asdell, 1962; Wegmann \& Hadjiisky, 1969; Rondell, 
1970; Schwartz \& Hoffmann, 1972). Current theories favour the action of enzymes on substrates in the follicular wall or fluid, rather than the notion of increasing intrafollicular pressure towards ovulation. Veterinarians have known for years that equine follicles become flaccid before ovulation, and measurements have shown that the hydrostatic pressure does not rise before rupture in rabbits (Blandau \& Rumery, 1963; Espey \& Lipner, 1963; Jung, 1965). Muscle contraction in the oviduct or ovary might contribute to follicular rupture as shown by the depressive effects of dibenzyline, an $\alpha$-adrenergic-blocking agent (Virutamasen, Hickok \& Wallach, 1971; Bell, 1972). Ovulation evidently involves specific changes in particular follicles, even if muscular contraction is involved, as exemplified by evidence that smaller follicles are often preovulatory in preference to larger ones. Theories involving specific enzymes were encouraged by findings in rabbits that inhibitors of protein synthesis blocked ovulation, and intrafollicular injections of enzymes induced rupture (Espey \& Lipner, 1965; Pool \& Lipner, 1966). The enzymes were believed to induce an increasing distensibility of the follicular wall especially in the stigma (Espey, 1967; Rondell, 1970), although an alternative explanation implies that a smaller effective wall thickness over the whole follicle would result first in the formation of a stigma and then its rupture close to the surface of the ovary (Rodbard, 1968). This type of rupture, with a gentle flow of fluid from it, is frequently observed at ovulation.

One of the most consistent observations on preovulatory follicles concerns the changes in mucopolysaccharides shortly before ovulation, as described above. A theory of follicular enlargement and ovulation was based on increasing colloid osmotic pressure through depolymerization of the mucopolysaccharides (Zachariae \& Jensen, 1958; Jensen \& Zachariae, 1958). Metachromatic staining in the antrum was reduced, changes occurred in the viscosity of the fluid and increases of up to three-fold in the colloid osmotic pressure were found in follicles approaching ovulation, these changes perhaps occurring under the influence of $\mathrm{LH}$ and involving follicular hyaluronidase. The active agent in fluids from large follicles could decrease the viscosity of fluid from smaller follicles. A rôle for hyaluronidase was also suggested by Schubert \& Wohlzogen (1957), the rate of the reaction being increased by $\mathrm{LH}$, but was not supported by the results of the intrafollicular injections of this enzyme (Espey \& Lipner, 1965).

Various other enzymes have been related to follicular rupture. Endopeptidase activity in the follicle was found to be present in the tissue of the ovary rather than in the follicular fluid (Jung, 1965). The pH optimum was 3.5; FSH stimulated and LH inhibited the activity of the enzyme in the fluid. Other enzymes, e.g. the glycylpeptidases and the acid and alkaline phosphatases, were found in follicular fluid, which was autolysed at acid $\mathrm{pH}$, but not under alkaline conditions. Once again, the intrafollicular injection of some of these enzymes failed to induce ovulation (Espey \& Lipner, 1965), nor is there any indication of acid conditions in the preovulatory follicle. Other enzymes studied in connection with follicular rupture have included papain, trypsin and one degrading albumin (Roemer, 1955; Krauss, 1965). More recently, enzymes with collagenolytic activity were examined, since they induced follicular rupture when injected into follicles (Espey \& Lipner, 1965), and changes in both distensibility and breaking strength of enlarging follicles were ascribed to modifications in the ground 
substance of the collagen fibrils. An enzyme resembling collagenase, located in the dome of the follicle, diffuses into follicular fluid and shows increasing activity towards the time of follicular rupture (Espey \& Rondell, 1968). The enzyme is also present in fluids covering the surface of the follicle (Rondell, 1970); but some doubt now arises about collagenase too, for a preparation of this enzyme from the ovary did not increase the distensibility of strips of pig follicles in vitro (Espey \& Stacey, 1970).

Several enzymes could be involved in inducing follicular changes leading to ovulation, as indicated by the diversity of those offered to explain follicular rupture. Detecting changing enzymic activity in follicles does not imply a causeeffect relationship with rupture, for several phenomena including oocyte maturation and changes in steroidogenesis occur at this time. Perhaps a purified enzyme will be obtained one day, although none has been identified so far. It is possible that several events occur simultaneously to induce follicular rupture. Attention is currently being given to the underlying physiological controls of follicular changes, such as the local effect of steroids on follicles (Lipner \& Greep, 1971) or the activation of collagenase by increasing amounts of prostaglandins and decreasing levels of oestrogen (Le Maire et al., 1973; Marsh et al., 1973). Enzyme activity during follicular rupture might be controlled by changing levels of proteinase inhibitors in follicular tissues of fluid. Such inhibitors have been found in human follicular fluids (M. H. Surani and R. G. Edwards, unpublished observations; Pl. 2, Fig. 3), although their relationship to those in serum and other tissues (Fritz \& Tschesche, 1971) remains to be clarified.

\section{FOLLICULAR FLUID AND THE OVIDUCT}

\section{Transport of the oocyte into the ampulla}

A major function of follicular fluid would seemingly be to help the oocyte in its escape from the follicle. The arrangement of the follicular contents changes as ovulation approaches, and the attachment of the oocyte and many granulosa cells to the follicular wall become weaker. The oocyte, with its attendant cells, is finally loosened from its attachment to the follicle, and lies free in the antrum. Movement of the oocyte through the antrum to the stigma at or just before ovulation is facilitated by the fluid.

Follicular fluid also plays a distinct rôle in the transport of the oocyte to the oviduct, especially in species where it is present in copious amounts. In animals such as the plains viscacha, where the antrum remains small (Weir, 1971), transport must be effected by different methods. Fluid is not released explosively at ovulation from most rupturing follicles of mammals, such as the rabbit, where it has been directly observed. Instead, it usually flows gently in a steady and regular manner from a gently-ruptured stigma (e.g. Walton \& Hammond, 1928; Blandau, 1968). Rupture may occur at the base of the stigma rather than at its apex. There are considerable species variations in the manner whereby the ovulating oocyte is collected into the ampulla (Blandau, 1969).

The species differences are probably reflected in the nature of the follicular fluid, and especially its viscosity. In guinea-pig, rabbit, monkey and human follicles, the oocyte is 'anchored' to the surface of the ovary as the fluid oozes from the follicle. Movements of the fimbria over the ovary in the region of the 
PLATE 3

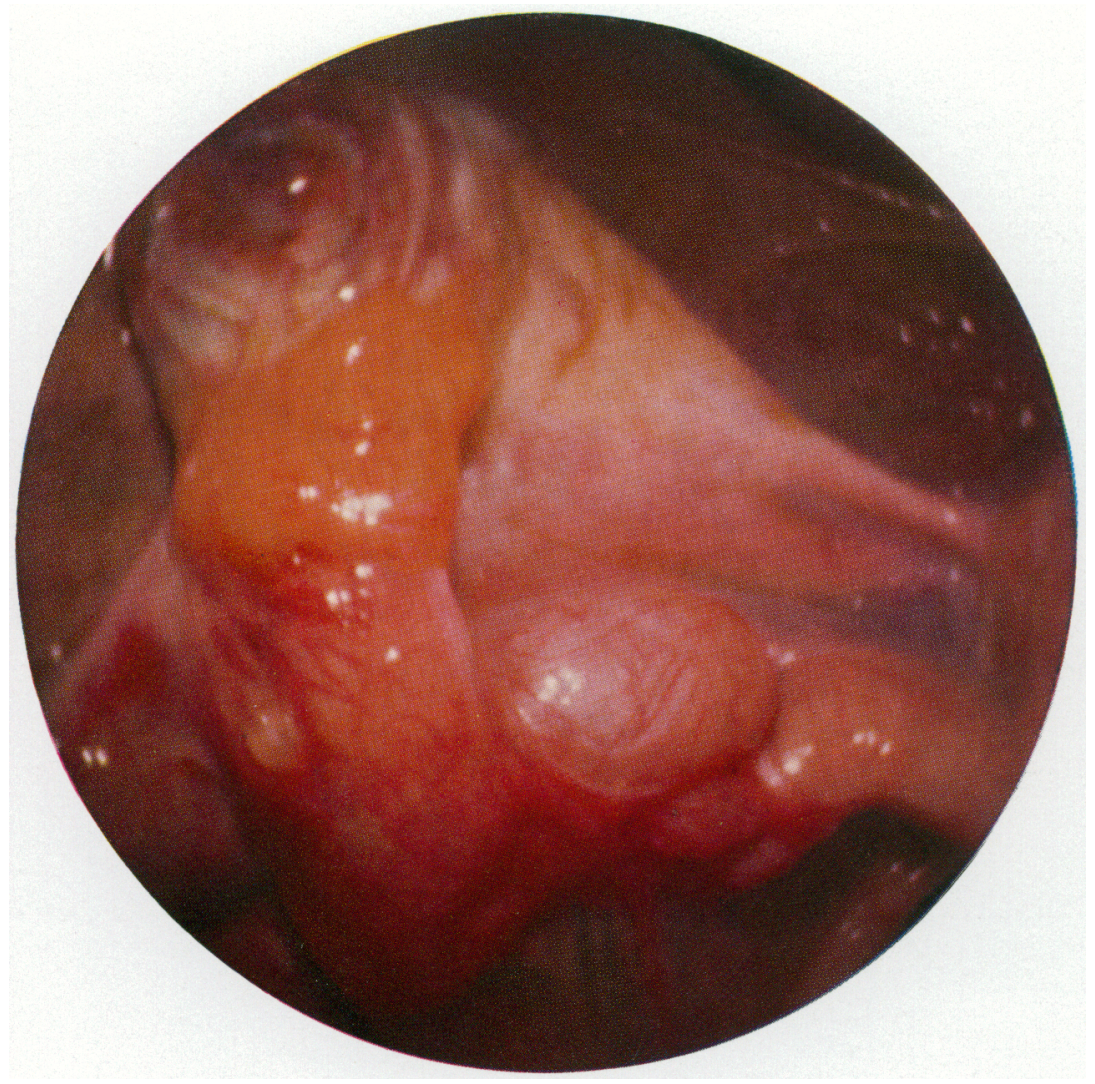

Fig. 5. Association between the fimbria and a large (preovulatory? follicle in a woman undergoing laparoscopy on the 1 th hay of her menstrual cycle. The fimbria appears to be approaching that part of the ovary containing the follicle, and the remainder of the oviduct extends through the lower part of the illustration. Blood vessels can just be seen traversing the surface of the follicle. Illustration by courtesy of Mr P. C. Steptoe. 
follicle create the conditions for the ciliary beat to sweep the oocytes gently from the ovary into the ampulla, although there are wide differences between species in the nature of such oviducal mobility (Elert, 1947; Westman, 1952; Doyle, 1956; Blandau, 1969; Jewett \& Dukelow, 1972) (Pl. 3, Fig. 5). Attachment of the oocyte to the surface of the ovary is evidently determined by the more viscous elements of the follicular fluid, and may be a property of hyaluronic acid (Blandau, 1971). Interference with the fimbriated end of the rabbit oviduct restricts oocytes to the ovarian surface for prolonged periods (Clewe \& Mastroianni, 1958).

The rôle of follicular fluid in ovulation is different in species such as rodents where the ovaries are enclosed in a membrane called the periovarial sac (Alden, 1942). A small opening in the base of this sac, connecting the cavity around the ovary with the peritoneal cavity, is closed at the time of ovulation (Wimsatt \& Waldo, 1945). Oocytes are shed into the cavity between the ovary and sac, and movements of the ovary and fimbria ensure the movement of the fluid therein. Oocytes are then drawn into the ampulla, as a result of ciliary beat in the fimbria. The follicular fluid contributes to the medium around the ovary in these species; the oocyte is not adherent to the ovary, and although the fimbria is mobile it appears to play a different rôle to the species described above (Blandau, 1971).

\section{Capacitation of spermatozoa}

A rôle for follicular fluid in the capacitation of spermatozoa was proposed when hamster eggs were fertilized in vitro by epididymal spermatozoa in the absence of oviducal or uterine secretions (Yanagimachi \& Chang, 1964; Barros \& Austin, 1967). Capacitation of hamster spermatozoa was then achieved by bovine follicular fluid (Gwatkin \& Andersen, 1969; Yanagimachi, 1969a, b), and mouse eggs were fertilized in the presence of this fluid (Iwamatsu \& Chang, 1969). Similar results using human follicular fluid were obtained with human, mouse and rat spermatozoa (Mukherjee \& Lippes, 1972). Three fractions were identified in the fluid by Yanagimachi: a toxin could be destroyed by heating and was probably complement; a dialysable component stimulated the activity of spermatozoa, and a non-dialysable component induced the acrosome change. The fraction causing acrosomal changes was evidently present in serum too (Yanagimachi, 1970). The activity of the non-dialysable component in serum or follicular fluid could arise through a naturally occurring antibody reactive with the acrosome (Beck, Edwards \& Young, 1962; Johnson, 1968). One suggestion, so far unproven, is that progesterone in follicular fluid or synthesized by the cumulus cells can induce the acrosome reaction (Edwards, 1970).

The difficulty in establishing a rôle for follicular fluid in capacitation has been compounded by recent work showing that eggs of mice, rabbits and hamsters can be fertilized in vitro after removal of the cumulus cells and repeated 'washing' (Fraser, Dandekar \& Vaidya, 1971; Miyamoto \& Chang, 1972; Pavlok \& McLaren, 1972). Follicular fluid is excluded in this situation unless it sticks to the zona pellucida or shares components with this membrane. The zona pellucida is evidently synthesized by granulosa cells (Merker, 1961; Stegner, 1970), and is histochemically similar (Jacoby, 1962). Cumulus cells are reported to play a 
rôle in capacitation (Gwatkin, Andersen \& Hutchinson, 1972), together with compounds liberated from the oocyte-'fertilisins'-according to Thibault \& Dauzier (1961) and not specified in recent work by Hartmann, Gwatkin \& Hutchinson (1972). Moreover, deciding on the rôle of components in the zona pellucida is difficult because removal of this membrane obviates the need for capacitation (Toyoda \& Chang, 1968). Indeed, capacitation in hamsters is reported to occur in the absence of the oocyte and its investments. The clearest conclusion is that follicular fluid now seems an unlikely candidate for inducing capacitation, although difficult to dispose of with finality.

\section{Effects in the oviduct}

The large concentrations of steroids in some samples of follicular fluid led to the suggestion that follicular fluid plays a part in oviducal physiology, for example in tubal transport of ova (Short, 1964a). This suggestion now seems less likely in view of recent evidence showing a steep decline in steroidogenesis in the preovulatory follicles of several species. A kinin found in the fluid of rabbit, cow and human follicles exerts an action on smooth muscle and on Fallopian tubes maintained in vitro (Ramwell, Shaw \& Jessup, 1969). Various assay methods showed the compound to be similar to bradykinin, and probably a polypeptide; it induced a slight lowering in the intraluminal pressure of bovine oviducts in vitro, and reduced the motility of rabbit oviducts. These authors suggest that the pain reported at ovulation (Mittelschmerz) may be due to the action of this compound on afferent fibres in the peritoneal tissues.

\section{Follicular immunoglobulins in the oviduct}

The concentrations of immunoglobulins in the fluid of the oviduct and uterus appear to be low (Edwards, 1969; Symons \& Herbert, 1971), and the search for antibodies there has largely been negative. Follicular fluid probably contributes a low quantity of immunoglobulin to the ampulla at ovulation. The effect must be of limited duration, but could be of great significance in some cases. Enough $\gamma$-globulin can be extracted by electrophoresis from an ovulated mass of hamster cumulus cells to be detected by immunoelectrophoresis (Pl. 2, Fig. 4) (Johnson, 1973). Such antibody could exert effects on spermatozoa and induce infertility, perhaps in women known to have antibodies against the husband's spermatozoa (Isojima, 1969). One infertile patient with circulating IgG and IgM against spermatozoa also possessed antibody activity in her follicular fluid (R. G. Edwards, P. C. Steptoe and J. M. Purdy, unpublished data). This field of study is largely unexplored in women, although the $\mathrm{ABO}$ isogglutinins (IgM?) have been found in follicular fluid (Heglar, 1962), and anti-spermatozoal antibodies in the follicular fluids of immunized heifers (Menge, 1970).

\section{CONCLUSIONS}

Follicular fluid is probably involved in several physiological processes. The evidence for its rôle in some of them appears to be unambiguous. Thus, during ovulation it provides a medium to carry the oocyte to the stigma and then to the oviduct. The viscous fluid could offer some protection to the oocyte at this time. 
Transport does not necessarily demand copious amounts of fluid, for the antrum is very small in the ovulatory follicle of some species.

The fluid might also provide supplies of nourishment to the oocyte and granulosa cells, by facilitating transport from plasma. This rôle must be fulfilled only during the later stages of follicular growth, for the oocyte enlarges considerably long before the fluid appears. Nevertheless, the curious anatomical combination whereby the granulosa is not vascularized, yet the basement membrane is permeable to almost all plasma components, could represent a compromise in which the follicle is nourished while haemorrhage from the granulosa at ovulation is avoided. Alternatively, there may be some purpose in the exclusion of the large plasma molecules from fluid, especially the components of complement. The situation in the follicle is clearly different from that in other parts of the genital tract, e.g. the seminiferous tubules, where plasma components are almost entirely excluded from the fluid.

Some other distinct characteristics of follicular fluid are not easy to explain. Concentrations of steroids are so high that finding a rôle for them seems almost compelling. This concentration of steroids might maintain a steady flow into the bloodstream during the follicular phase, condition the growth of neighbouring follicles and stimulate meiosis in oocytes or mitosis in cells of the rapidlyexpanding follicle. The fluid may exert some effects in the oviduct, but the evidence for such endocrinological, immunological or pharmacological effects there is not convincing.

The widespread occurrence of an antral follicle in mammalian species testifies to its evolutionary significance, and some selective advantages must obviously be associated with this method of follicular growth and rupture. The rôle of the fluid in ovulation will perhaps become more obvious when the causes of follicular swelling and rupture are clarified. It is clear now that this small reservoir of fluid reflects the biochemical and especially the endocrinological activity of the follicle, and thus serves as a guide to its growth and differentiation.

\section{REFERENCES}

Abraham, G. E., Odell, W. D., Edwards, R. G. \& Purdy, J. M. (1970) Solid-phase radioimmunoassay of estrogens in biological fluids. In: Steroid Assay by Protein Binding. Geneva, 1970. Eds. E. and A. Diczfalusy. Karolinska Institutet, Stockholm.

Alden, R. H. (1942) The periovarial sac in the albino rat. Anat. Rec. 83, 421.

ARATEI, H. (1972) Ovarian follicle and permeability of the membrane. Revue Roum. Endocr. 9, 79.

Asdell, S. A. (1962) The mechanism of ovulation. In: The Ovary, vol. 1, p. 435. Ed. S. Zuckerman. Academic Press, London.

BaKer, T. G. (1972) Gametogenesis. In: The Use of Non-Human Primates in Research on Human Reproduction, p. 18. Eds. E. Diczfalusy and C. C. Standley. Karolinska Institutet, Stockholm.

Barros, E. \& Austin, C. R. (1967) In vitro fertilization and the acrosome reaction in the hamster. F. exp. Zool. 166, 317.

Beck, L. R. \& Shelden, R. M. (1972) Antigenicity of rat follicular fluid. Fert. Steril. 23, 910.

Beck, J. S., Edwards, R. G. \& Young, M. R. (1962) Immune fluorescence technique and the isoantigenicity of mammalian spermatozoa. F. Reprod. Fert. 4, 103.

BeLL, C. (1972) Autonomic nervous control of reproduction: circulatory and other factors. Pharmac. Rev. 24, 657.

BEN-OR, S. (1963) Morphological and functional development of the ovary of the mouse. I. Morphology and histochemistry of the developing ovary in normal conditions and after FSH treatment. $\mathcal{F}$. Embryol.exp. Morph. 11, 1.

Betteridge, K. J., Kelly, W. A. \& Marston, J. H. (1970) Morphology of the rhesus monkey ovary near the time of ovulation. $\mathcal{J}$. Reprod. Fert. 22, 453. 
BJersing, L. \& Carstensen, H. (1964) The role of the granulosa cell in the biosynthesis of ovarian steroid hormones. Biochim. biophys. Acta, 86, 639.

Bjersing, L., Hay, M. F., Kann, G., Moor, R. M., Naftolin, F., Scaramuzzi, R. J., Short, R. V. \& YounGLaI, E. V. (1972) Changes in gonadotrophins, ovarian steroids and follicular morphology in sheep at oestrus. 7 . Endocr. 52, 465.

BJersing, L. \& YoungLai, E. V. (1972) Steroid hormones and ultrastructure of the equine graafian follicle. Z. Zellforsch. mikrosk. Anat. 132, 357.

BjöRKMAN, N. (1962) A study of the ultrastructure of the granulosa cells of the rat ovary. Acta anat.51, 125.

BLAha, G. C. \& LeAvitT, W. W. (1971) The distribution of $\Delta^{5}-3 \beta$-hydroxysteroid activity in the golden hamster during the estrous cycle, pregnancy and lactation. Biol. Reprod. 3, 362.

Blandau, R. L. (1968) Follicular growth, ovulation and egg transport. In: The Ovary. Ed. H. C. Mack. C. C. Thomas, Springfield.

Blandau, R. J. (1969) Gamete transport-comparative aspects. In: The Mammalian Oviduct. Eds. E. S. E. Hafez and R. J. Blandau. University of Chicago Press.

BLANDAU, R. J. (1971) Normal egg transport through the oviducts of mammals. In: Pathways to Conception. Ed. A. I. Sherman. C. C. Thomas, Springfield.

BLANDAU, R. J. \& Rumery, R. E. (1963) Measurement of intra-follicular pressure on ovulatory and preovulatory follicles of the rat. Fert. Steril. 14, 330.

Boström, H. \& Odeblad, E. (1952) Autoradiographic observations on the uptake of $S^{35}$ in the genital organs of the female rat and rabbit after injection of labelled sodium sulfate. Actaendocr., Copenh. 10,89.

BRADBURY, J. T. (1961) Direct action of oestrogen on the ovary of the immature rat. Endocrinology, 68, 115.

Braden, A. W. H. (1952) Properties of the membranes of rat and rabbit eggs. Aust. F. biol. Sci. B, 5, 460.

Brambell, F. W. R. (1960) Ovarian changes. In: Marshall's Physiology of Reproduction, vol. 1, part 1, chap. 5. Ed. A. S. Parkes. Longmans Green, London.

BRAND, A. (1970) Enkele micromorfologische en biochemische aspecten van de ovaria van het Texelse schaap tijdens het oestrusseizoen. Ph.D. thesis, State University of Utrecht.

Braunsberg, H., Irvine, W. T. \& James, V. H.J. (1967) A comparison of steroid hormone concentration in human tissues, including breast cancer. Br. 7. Cancer, $4,714$.

Bulmer, D. (1965) A histochemical study of ovarian cholinesterases. Acta anat. 62, 254.

ButLer, H. (1971) Oogenesis and folliculogenesis. In: Comparative Reproduction of Nonhuman Primates. Ed. E. S. E. Hafez. C. C. Thomas, Springfield.

Byskov, A. G. S. (1969) Ultrastructural studies on the preovulatory follicle of the mouse ovary. $Z$. Zellforsch. mikrosk. Anat. 100, 285.

Caravaglios, R. \& Cilotti, R. J. (1957) A study of the proteins in the follicular fluid of the cow. $\mathcal{F}$. Endocr. 15, 273.

Caucig, H., Friedrich, F., Hager, R. \& Golob, E. (1971) Enzymes in follicular and cyst fluid in human ovaries. Acta endocr., Copenh. 66, Suppl. 152, 52.

Gerlettr, P. \& Zichella, L. (1961) Nucleotidases, nucleotides, vitamins and coenzymes in the follicular fluid of human ovary. Clinica chim. Acta, 6, 581 .

Channing, C. P. (1969) The use of tissue culture of granulosa cells as a method of studying the method of luteinisation. In: The Gonads. Ed. K. W. McKerns. North Holland Publishing Co., Amsterdam.

Channing, C. P. (1970) Influences of the in vivo and in vitro hormonal environment upon luteinization in tissue culture. Recent Prog. Horm. Res. 20, 589.

Channing, C. P. (1972) Comparison of number of gonadotropin receptors in granulosa cells harvested from small, medium and large pig follicles. (Abstract). Biol. Reprod. 7, 127.

Clewe, T. H. \& MAstroianni, L. (1958) Mechanisms of ovum pickup. I. Functional capacity of rabbit oviducts ligated near the fimbria. Fert. Steril. 9, 13.

CROOKE, A. C. (1969) The use of human pituitary gonadotrophins in some aspects of ovarian pathology. In: The Ovary. Eds. W. Inguilla and R. B. Greenblatt. C. C. Thomas, Springfield.

Deane, H. W. (1952) Histochemical observations on the ovary and oviduct of the albino rat during the estrous cycle. Am. F. Anat. $91,363$.

Desjardins, C., Kirton, K. T. \& Hafs, H. D. (1966) Some chemical, immunochemical and electrophoretic properties of bovine follicular fluid. F. Reprod. Fert. 11, 237.

DoyLE, J. B. (1956) Tubo-ovarian mechanism: observations at laparotomy. Obstet. Gynec., N.Y. 6, 686.

Dufour, J., Gunther, J. \& CAsida, L. E. (1972) Intraovarian relationship between corpora lutea and ovarian follicles in ewes. Am. F. vet. Res. 33, 1445.

EDWARDs, R. G. (1962) Meiosis in ovarian oocytes of adult mammals. Nature, Lond. 196, 446.

EDwards, R. G. (1969) Transmission of antibodies across membranes of the reproductive tract. In: Immunology and Reproduction, p. 28. Ed. R. G. Edwards. Int. Plann. Parenthood Fedn, London.

EDwards, R. G. (1970) Fertilization of human eggs in vitro. 9th Int. Embryological Conference, Moscow. Plenum Press, New York. 
Edwards, R. G. \& SirLIN, J. L. (1958) Radioactive tracers and fertilization in mammals. Endeavour, 17, 42.

Edwards, R. G., Steptoe, P. C., Abraham, G. E., Walters, E., Purdy, J. M. \& Fotherby, K. (1972) Steroid assays and preovulatory follicular development in human ovaries primed with gonadotrophins. Lancet, ii, 611.

ELERT, R. (1947) Der Mechanismus der Eiabnahme im Laparoskop. Zentbl. Gynäk. 69, 38.

El-Fouly, M. A., Cook, B., Nekola, M. \& Nalbandov, A. V. (1970) Role of the ovum in follicular luteinization. Endocrinology, 87, 288.

Ellsworth, L. R. \& ARMSTRONG, D. T. (1971) Effect of LH on luteinization of ovarian follicles transplanted under the kidney capsule in rats. Endocrinology, 88, 755.

Eshkol, A., Lunenfeld, B. \& Peters, H. (1970) Ovarian development in infant mice. Dependence on gonadotrophic hormones. In: Gonadotrophins and Ovarian Development, p. 249. Eds. W. R. Butt, A. C. Grooke and M. Ryle. Livingstone, Edinburgh.

Espey, L. (1967) Tenacity of porcine Graafian follicle as it approaches ovulation. Am. F. Physiol. 212, 1397.

ESPEy, L. \& LipNer, H. (1963) Measurements of intra-follicular pressures in the rabbit ovary. Am. $\mathcal{J}$. Physiol. 205, 1067.

ESPEy, L. \& LipNER, H. (1965) Enzyme-induced rupture of rabbit Graafian follicle. Am. F. Physiol. 208, 208.

Espey, L. \& Rondell, P. (1968) Collagenolytic activity in the rabbit and sow Graafian follicle during ovulation. Am. J. Physiol. 214, 326.

EsPey, L. L. \& STACEY, S. (1970) Failure of an ovarian collagenolytic extract to decompose the connective tissue in the mature sow Graafian follicle. Fedn Proc. Fedn Am. Socs exp. Biol. 29, 833.

Fraser, L. R., Dandekar, P. V. \& VAIDYA, K. A. (1971) In vitro fertilization of tubal rabbit ova partially or totally denuded of follicular cells. Biol. Reprod. 4, 229.

Fritz, H. \& Tschesche, H. (Editors) (1971) Proteinase inhibitors. Proc. Int. Research Conf., Munich, 1970. W. de Gruyter, Berlin, New York.

Grorgi, E. P. (1963) The determination of steroids in cyst fluid from human polycystic ovaries. F. Endocr. $27,225$.

GroRgI, E. P. (1965) Steroids in cyst fluid from ovaries of normally menstruating women and of women with functional uterine bleeding. 7. Reprod. Fert. 10, 309.

Grorgi, E. P. (1967) Determination of free and conjugated oestrogens in fluid from human ovaries. F. Endocr. 37, 211.

Grorgi, E. P., AdDis, M. \& Colombo, G. (1969) The fate of free and conjugated oestrogens injected into the Graafian follicles of equines. 7. Endocr. 45, 37.

GLAss, L. E. (1971) Transmission of maternal proteins into oocytes. In: Intrinsic and Extrinsic Factors in Early Mammalian Development. Ed. G. Raspé. Pergamon Press, Vieweg.

GothIE, S. (1954) La réponse folliculaire et ovulaire. Emploi des traceurs dans l'étude de la gonadotrophine choriale. Annls Endocr. 15, 579.

GouÉzou, J. M. (1969) Fonctions physiques du follicle ovarien. Proprietés du liquide folliculaire. In: L'Ovulation. Ed. R. Moricard. Masson, Paris.

Greep, R. O. (1973) The gonadotrophins and their releasing factors. F. Reprod. Fert., Suppl. 20, 1.

Gwatkrn, R. B. L. \& ANDERSEN, O. F. (1969) Capacitation of hamster spermatozoa by bovine follicular fluid. Nature, Lond. 224, 111.

Gwatkin, R. B. L., Andersen, O. F. \& Hutchinson, C. F. (1972) Capacitation of hamster spermatozoa in vitro: the rôle of cumulus components. 7 . Reprod. Fert. 30, 389.

HANSEN, K. B. (1972) Immunofluorescent studies on human spermatozoa. III. Immunoglobulin classes of human spermatozoal antibodies. Clin. exp. Immun. 10, 243.

HANSEN, K. B. \& HJoRT, T. (1971) Immunofluorescent studies on human spermatozoa. II. Characterisation of spermatozoal antigens and their occurrence in normal and infertile women. Clin. exp. Immun. 9, 21.

Hartmann, J. F., Gwatkin, R. B. L. \& Hutchinson, C. F. (1972) Early contact interactions between mammalian gametes in vitro. Evidence that the vitellus influences adherence between sperm and zona pellucida. Proc. natn. Acad. Sci. 69, 2767.

Hayashi, H., Hayashi, M., Amano, H. \& Yanagisawa, I. (1973) Separation of a substance containing ribulose in human follicular fluid. 7 th World Cong. Fertility and Sterility, Tokyo. Excerpta med. Fdn, Amsterdam (in press).

Heglar, R. (1962) Relationship between follicular fluid ABO(H) systems and fertility. Int. 7. Fert. 7, 321.

Heimburger, N., Haupt, H. \& Schwick, H. G. (1971) Proteinase inhibitors of human plasma. In: Proteinase Inhibitors. Eds. H. Fritz and H. Tschesche. W. de Gruyter, Berlin, New York.

Herve, R., Sergent, P. \& Robey, M. (1968) Antigenic properties of the ovary. Their demonstration in ovarian tissue, follicular fluid and cervical mucus. Presse méd. 76, 421. 
Hilliard, J. \& Eaton, L. W. (1971) Estradiol-17 8 , progesterone and 20 $\alpha$-hydroxy-pregn-4-en-3-one in rabbit ovarian venous plasma. 2. From mating through implantation. Endocrinology, 89, 522.

Holzinger, M. (1972) Das Verhalten der unspezifischen Esterasen in den Tertiärfollikeln des Ovars Normales und Oestrogenbehandelter Ratten. Acta histochem. 42, 41.

Hunter, R. L. \& KNeIske, K. M. (1957) Quantitative study of non-specific esterase in the rat ovary. 7. Histochem. Cytochem. 5, 154.

IsojIMA, S. (1969) Relationship between antibodies to spermatozoa and sterility in females. In: Immunology and Reproduction, p. 267. Ed. R. G. Edwards. Int. Plann. Parenthood Fedn, London.

Iwamatsu, T. \& Chang, M. C. (1969) In vitro fertilization of mouse eggs in the presence of bovine follicular fluid. Nature, Lond. 224, 919.

JAcoBy, F. (1962) Ovarian histochemistry. In: The Ovary. Ed. S. Zuckerman. Academic Press, New York.

JENSEN, C. E. \& ZAGHARIAE, F. (1958) Studies on the mechanism of ovulation. Isolation and analysis of acid mucopolysaccharides in bovine follicular fluid. Acta endocr., Copenh. 27, 356.

JEWETT, D. A. \& DuKelow, W. R. (1972) Serial observations of follicular morphology near ovulation in Macaca fascicularis. F. Reprod. Fert. 31, 287.

Johansson, E. D. B., NeILl, J. D. \& KNoBIL, E. (1968) Periovulatory progesterone concentration in the peripheral plasma of the rhesus monkey with a methodological note on the detection of ovulation. Endocrinology, 82, 143.

Johnson, M. H. (1968) The characterization of a natural antibody in normal guinea-pig serum reacting with homologous spermatozoa. F. Reprod. Fert. 16, 503.

Jornson, M. H. (1973) Physiological mechanisms for the immunological isolation of spermatozoa. In: Advances in Reproductive Physiology, Vol. VI. Ed. M. W. H. Bishop. Logos Press, London.

JONES, E. E. \& NALBANDOV, A. V. (1972) Effects of intrafollicular injection of gonadotropins on ovulation or luteinization of ovarian follicle. Biol. Reprod. 7, 87.

Jung, G. (1965) Biochemische Untersuchungen über Enzyme im Ovarium. In: Enzyme des Ovariums. Fortsch. Geburtsh. Gynäk. 23, 77.

Jung, G. \& HeLd, H. (1959) Ủber fermente in der follikelflüssigkeit. Arch. Gynaek. 192, 146.

KEYES, P. L. (1969) Luteinizing hormone: action on the graafian follicle in vitro. Science, N.r. 164, 846.

Keyes, P. L., Canastar, G. D. \& Miller, J. B. (1972) Studies on luteinization of transplanted rabbit follicles exposed to LH, actinomycin D or adenosine $3^{\prime} 5^{\prime}$-cyclic-monophosphate in vitro. Endocrinology, 91, 197.

KNoBIL, E. (1972) Hormonal control of the menstrual cycle and ovulation in the rhesus monkey. In: The Use of Non-Human Primates in Research on Human Reproduction, p. 137. Eds. E. Diczfalusy and C. C. Standley. Karolinska Institutet, Stockholm.

KoERING, M. J. (1969) Cyclical changes in ovarian morphology during the menstrual cycle in Macaca mulatta. Am. 7. Anat. 126, 73.

KRAUSs, W. (1965) see JunG, G. (1965).

Le MaIre, W. J., Mills; T., Ito, Y. \& Marsh, J. M. (1972) Inhibition by 3'-5'-cyclic AMP of luteinization induced by intrafollicular injection of luteinizing hormone. Biol. Reprod. 6, 109.

Le Maire, W. J., Young, N. S. T., Robinson, H. H. \& Marsh, J. M. (1973) Preovulatory changes in the concentration of prostaglandins in rabbit Graafian follicles. Prostaglandins, 3, 367.

LIPNER, H. \& GREEP, R. O. (1971) Inhibition of steroid oogenesis at various sites in the biosynthetic pathway in relation to induced ovulation. Endocrinology, 88, 602.

LunaAs, T. (1964) Distribution of oestrone and oestradiol in bovine ovary. Acta vet. scand. 5, 35.

Lutwak-Mann, C. (1954) Note on the chemical composition of bovine follicular fluid. F. agric. Sci., Camb. 44, 477.

McGaughey, R. W. \& Daniel, J. C., JR (1972) Protein patterns of ovarian follicular fluids from pigs. (Abstract). Biol. Reprod. 7, 128.

MaKerns, K. W., Ed. (1969) The gonads. North Holland Publishing Co., Amsterdam.

Manarang-Pangan, S. \& Menge, A. C. (1971) Immunologic studies on human follicular fluid. Fert. Steril. 22, 367.

Mancini, R. E., Vilar, O., Dellacha, J. M., Davidson, O. W. \& Alvarez, B. (1962) Extravascular distribution of fluorescent albumin, globulin and fibrinogen in connective tissue. $\mathcal{F}$. Histochem. Cytochem. 10, 194.

Mancini, R. E., Vilar, O., Gomez, G., Dellacha, J. M., Davidson, O. W. \& Castro, A. (1961) Histological study of distribution of fluorescent serum proteins in connective tissue. $\mathcal{F}$. Histochem. Cytochem. 9, 356.

Mancini, R. E., Vilar, O., Heinrich, J. J., Davidson, O. W. \& Alvarez, B. (1963) Transference of circulating labelled serum proteins to the follicle of the rat ovary. $\mathcal{F}$. Histochem. Cytochem. 11, 80.

Marsh, J. M., Mills, T. M. \& Le Maire, W. J. (1972) Cyclic AMP synthesis in rabbit Graafian follicles and the effect of luteinising hormone. Biochim. biophys. Acta, 273, 389. 
Marsh, J. M., Mills, T. M. \& Le Maire, W. J. (1973) Preovulatory changes in the synthesis of cyclic AMP by rabbit graafian follicles. Biochim. biophys. Acta, 304, 197.

Menge, A. C. (1970) Immune reactions and infertility. J. Reprod. Fert., Suppl. 10, 171.

Merker, H. J. (1961) Elektronenmikroskopische untersuchungen über die Bildung der Zona pellucida in den Follikeln des Kaninchenovars. Z. Zellforsch. mikrosk. Anat. 54, 677.

Mryamoto, H. \& Chang, M. C. (1972) Fertilization in vitro of mouse and hamster eggs after removal of follicular cells. F. Reprod. Fert. 30, 309.

Moore, N. W., Barrett, S., Brown, J. B., Schindler, I., Smith, M. A. \& Smyth, B. (1969) Oestrogen and progesterone content of ovarian vein blood of the ewe during the oestrous cycle. F. Endocr. 44, 55.

Moore, R. M., Hay, M. F. \& Caldwell, B. V. (1971) The sheep follicle: relation between the sites of steroicl dehydrogenase activity, gonadotrophic stimulation and steroid production. (Abstract). 7. Reprod. Fert. $27,484$.

Moricard, R. (1967) Gonadotrophines, méiose, ovulation. Cytophysiologie et applications humaines. I. Anatomie microscopique, hormonologie éxperimentale ovarienne, radio-isotopes. Revue fr. Gynéc. Obstet. 62, 591 .

Moricard, R. (1968) Gonadotrophines, méiose, ovulation. Cytophysiologie et applications humaines. II. Fonction méiogène du liquide folliculaire. Microscopie electronique. 2. Ovocyte humain. Essaide cytologie ultrastructurale comparée. Revue fr. Gynéc. Obstét. 63, 643.

Moricard, R., Ed. (1969) L'Ovulation. Masson, Paris.

MuxhERJEE, A. B. \& Lippes, J. (1972) Effect of human follicular and tubal fluids on human, mouse and rat spermatozoa in vitro. Can. F. Genet. Cytol. 14, 167.

Nalbandov, A. V. (1972) Interaction between oocytes and follicular cells. In: Oogenesis, p. 513. Eds. J. D. Biggers and A. W. Schuetz. Butterworths, London.

NAti, G. \& Odeblad, E. (1955) Observations on the uptake of radiophosphate and radiosulphate in the mouse ovary under some hormonal conditions. Acta endocr., Copenh. 19, 43.

Nekola, M. V. \& Nalbandov, A. V. (1971) Morphological changes of rat follicular cells as influenced by oocytes. Biol. Reprod. 4, 154 .

NoRman, R. L. \& GREENWALd, G. S. (1971) Effect of phenobarbital, hypophysectomy, and X-irradiation on preovulatory progesterone levels in the cyclic hamster. Endocrinology, 89, 598.

Norman, R. L. \& Greenwald, G. S. (1972) Follicular histology and physiological correlates in the preovulatory hamster. Anat. Rec. 173, 95.

Odeblad, E. (1952) A biophysical study on the ovarian follicular fluid. Acta endocr., Copenh. 11, 269.

Odeblad, E. (1954) Studies on the physiology of the follicular fluid. Acta endocr., Copenh. 15, 313.

Odeblad, E. \& BoströM, H. (1953) Time-picture relation study with autoradiography on uptake of labelled sulphate in graafian follicles of rabbit. Acta radiol. 39, 137.

Olds, D. \& VanDemark, N. L. (1957) Composition of luminal fluids in bovine female genitalia. Fert. Steril. 8, 345.

Palla, V. (1950) Richerche istochemische sulla pseudomucina del 'liquor folliculi' ed observazioni sulla sua sensibilita agli enzimi mucinolitici in rapporto al mechanismo della fecondazione. Minerva Ginec. 2, no. 11.

PARKEs, A. S. (1929) Internal secretions of the ovary. Longmans Green, London.

Pascu, T., Dema, A., Mihai, D., Lunca, H. \& Salageanu, G. (1968) Values of Ca, Mg and gl ucose in different phases of the oestral cycle, in the follicular fuid and in the blood of the same cows, also in the fluid of ovarian follicular cysts and in the blood of the same cows. VIe Congres de Reproduction et Insémination Artificielle, Paris. Institute National de la Recherche Agronomique, France.

Pascu, T., Mihai, D. \& Lunca, H. (1969) Concentration du sodium et du potassium dans le liquide folliculaire normal et dans le liquide des kystes folliculaires ovariens, ainsi que dans le sang des mêmes vaches. Recl. Méd. vét. Ec. Alfort. 145, 1283.

Pascu, T., Suteanu, M. \& Lunca, H. (1970) Concentration de la vitamine C dans le liquide folliculaire normal, pendant les différentes phases du cycle oestral et dans le liquide des kystes ovariens (folliculaires et lutéiniques), ainsi que dans le sang des mêmes vaches. Recl. Méd. vét. Ec. Alfort. 146, 1021.

Pascu, T., Tudorascu, R., Stanciolu, N. \& Lunca, H. (1971) Concentrations des protéines totales et des fractions protéiques dans le liquide folliculaire normal, pendant les différentes phases du cycle oestral, et dans le liquide des kystes folliculaires ovariens, ainsi que dans le sang des mêmes vaches. Recl. Méd. vét. Ec. Alfort. 147, 979.

Pavlok, A. \& Mclaren, A. (1972) The rôle of cumulus cells and the zona pellucida in fertilization of mouse eggs in vitro. J. Reprod. Fert. 29, 91 .

Pecknam, B. \& Kiekhofer, W. (1959) The movement of tritium-labelled water in the human ovarian follicle. Am. 7. Obstet. Gynec. 78, 1012.

Petkov, K., Antonov, S. \& Dzhurova, I. (1969) Elements and trace elements in normal and abnormal ovaries from heifers and cows. I. $\mathrm{Zn}$ and $\mathrm{Cu}$ content in follicular fluid and ovarian cysts. Vet. Med. Nauki. Sofia, 6, 91. 
POoL, W. R. \& LIPNER, H. (1966) Inhibition of ovulation by antibiotics. Endocrinology, 79, 858.

Rajaniemi, H. \& Vanha-Pertulla, T. (1972) Specific receptor for LH in the ovary: evidence by autoradiography and tissue fractionation. Endocrinology, 90, 1.

Ramwell, P. W., Shaw, J. E. \& Jessup, S. J. (1969) Follicular fluid kinin and its action on the Fallopian tube, Endocrinology, 84, 931 .

Rodbard, D. (1968) Mechanics of ovulation. 7. clin. Endocr. Metab. 28, 849.

Roemer, H. (1955) Die Kontrolle der Ovarialfunktion durch den Nachweis eines spezifischen proteolytischen Fermente. Arch. Gynaek. 186, 259.

Rondeld, P. (1970) Biophysical aspects of ovulation. Biol. Reprod., Suppl. 2, 64.

Ryan, R. J. \& Petro, Z. (1966) Steroid biosynthesis by human ovarian granulosa and thecal cells. 7. clin. Endocr. Metab. 26, 46.

Ryan, K. J., Petro, Z. \& Karser, J. (1968) Steroid formation by isolated and recombined ovarian granulosa and thecal cells. 7. clin. Endocr. Metab. 28, 355.

Ryan, K. J. \& Short, R. V. (1965) Formation of estradiol by granulosa and theca cells of the equine ovarian follicle. Endocrinology, 76, 108.

Sanyal, M. K., Nudemberg, F., Berger, M. \& Taymor, M. L. (1972) Development of the Graafian follicle in the human ovary: correlation of stages of meiosis in ovum and steroidal hormone concentrations in antrum fluid and follicular growth. (Abstract). 4 th int. Congr. Endocr., Washington, D.C. p. 171 (in press).

Schubert, G. \& Wohlzogen, F. X. (1957) Fermentative Steurung der Ovulation. Wien med. Wschr. $109,267$.

Schwartz, N. B. \& Hoffmann, J. C. (1972) Ovulation: basic aspects. In: Reproductive Biology. Eds. H. Balin and S. Glasser. Exerpta med. Fdn, Amsterdam.

Shalgi, R., Kraicer, P. F. \& Soferman, N. (1972a) Gases and electrolytes of human follicular fluid. 7. Reprod. Fert. 28, 335.

Shalgi, R., Kraicer, P. F. \& Soferman, N. (1972b) Human follicular fluid. (Abstract). F. Reprod. Fert. 31, 515.

Shivers, C. A., Metz, G. B. \& Lutwak-Mann, C. (1964) Some properties of pig follicular fluid. $\mathcal{J}$. Reprod. Fert. 8, 115.

SHort, R. V. (1960a) Steroids present in the follicular fluid of the mare. F. Endocr. 20, 147.

SHoRT, R. V. (1960b) Identification of 19-norandrostenedione in follicular fluid. Nature, Lond. 188, 232.

SHort, R. V. (1961a) $\Delta^{5}$-3 $\beta$-hydroxysteroids in the follicular fluid of the mare. F. Endocr. 23, 277.

SHORT, R. V. (1961b) Steroid concentrations in the follicular fluid of mares at various stages of the reproductive cycle. $\mathcal{F}$. Endocr. 22, 153.

Short, R. V. (1962a) Steroids present in the follicular fluid of the cow. F. Endocr. 23, 401.

SHORT, R. V. (1962b) Steroids in the follicular fluid and corpus luteum of the mare. A 'two-cell type' theory of ovarian steroid synthesis. F. Endocr. 24, 59.

SHORT, R. V. (1962c) Steroid concentration in normal follicular fluid and ovarian cyst fluid from cows. 7. Reprod. Fert. 4, 27.

SHORT, R. V. (1962d) Further observations on the defective synthesis of ovarian steroids in the SteinLeventhal syndrome. F. Endocr. 24, 359.

Short, R. V. (1964a) Ovarian steroid synthesis and secretion in vivo. Recent Prog. Horm. Res. 20, 303.

SHORT, R. V. (1964b) Steroid concentrations in the fluid from normal and polycystic (Stein-Leventhal) ovaries. Proc. 2nd Int. Congr. Endocr., London. Excerpta. med. Congr. Series No. 83.

SHort, R. V. \& London, D. R. (1961) Defective biosynthesis of ovarian steroid hormones in the SteinLeventhal syndrome. Br. med. F. i, 1724.

Sмiтн, J. T. (1937) Rupture of graafian follicles. Am. 7. Obstet. Gynec. 33, 820.

SMIтH, O. W. (1960) Estrogens in the ovarian fluids of normally menstruating women. Endocrinology, 67, 698.

Sommerville, I. F. (1969) Steroid analysis in the study of ovarian function. In: The Ovary. Eds. W. Inguilla and R. B. Greenblatt. C. C. Thomas, Springfield.

Stallaup, O. T. (1970) Enzyme activity of bovine follicular fluid. (Abstract). 7. Dairy Sci. 53, 382

STEGNER, H. E. (1970) Electron microscope studies of the interstitial tissue in the immature mouse ovary. In: Gonadotrophins and Ovarian Development, p. 232. Eds. W. R. Butt, A. C. Crooke and M. Ryle. Livingstone, Edinburgh.

Steptoe, P. C. \& Edwards, R. G. (1970) Laparoscopic recovery of preovulatory human oocytes after priming of ovaries with gonadotrophins. Lancet, $\mathbf{i}, 683$.

Symons, D. B. A. \& Herbert, J. (1971) Incidence of immunoglobulins in fluid of the rabbit genital tracts and the distribution of Ig-G globulin in the tissues of the female tract. 7 . Reprod. Fert. 24, 55.

TAkIKawa, H. (1966) Binding of steroids to follicular fluid proteins. In: Steroid Dynamics, p. 217. Eds. G. Pincus, T. Nakao and J. F. Tait. Academic Press, New York. 
Takikawa, H. \& Yoshinaga, S. (1968) Isolation of oestrogen binding proteins from follicular fluids of the cow ovary. 3rd Int. Congr. Endocr., Mexico. Excerpta med. Fdn, Amsterdam.

Thibault, C. \& Dauzier, L. (1961) 'Fertilisines' et fécondation en vitro de l'oeuf de la lapine. Annls Biol. anim. Biochim. Biophys. 1, 277.

Toyoda, Y. \& Chang, M. C. (1968) Sperm penetration of rat eggs in vitro after dissolution of the zona pellucida by chymotrypsin. Nature, Lond. 220, 589 .

TSAFriri, A., LindNER, H. R., ZoR, O. \& LAMPRECHT, S. A. (1972) In-vitro induction of meiotic division in follicle-enclosed rat oocytes by LH, cyclic AMP and prostaglandin $\mathbf{E}_{2}$. F. Reprod. Fert. $31,39$.

Vande Wiele, R. L., Bogumil, J., Dryenfirth, I., Ferin, M., Jewelewicz, R., Warren, M., RizkalLAH, T. \& MikhaIL, G. (1970) Mechanisms regulating the menstrual cycle in women. Recent Prog. Horm. Res. 26, 63.

Virutamasen, P., Hickok, R. L. \& Wallach, E. E. (1971) Local ovarian effects of catecholamines on human chorionic gonadotropin-induced ovulation in the rabbit. Fert. Steril. 22, 235.

von Kaulla, K. N., Aikawa, J. K. \& Petrigrew, J. D. (1958) Concentration in the human ovarian follicular fluid of radioactive tracers and drugs circulating in the blood. Nature, Lond. 182, 1238.

Walton, H. \& Hammond, J. (1928) Observation on ovulation in the rabbit. F. exp. Biol. 6, 190.

WEgmanN, R. \& HAdjusKy, P. (1969) L'equipement enzymatique du follicle mûr. Son rôle dans la rupture folliculaire. In: L'Ovulation. Ed. R. Moricard. Masson, Paris.

WEIR, B. J. (1971) The reproductive organs of the female plains viscacha, Lagostomus maximus. F. Reprod. Fert. 25, 365.

Westman, A. (1952) Investigations into the transport of the ovum. In: Studies on the Testes and Ovary, Eggs and Sperm, p. 163. Ed. E. T. Engle. C. C. Thomas, Springfield.

Wimsatt, W. A. \& WaLdo, C. M. (1945) The normal occurrence of a peritoneal opening in the bursa ovarii of the mouse. Anat. Rec. 93, 47.

Wingate, A. L. (1970) A histochemical study of the hamster ovary. (Abstract). Anat. Rec. 166, 399.

WURTMAN, R. J. (1964) Effect of LH on blood flow. Endocrinology, 75, 927.

YANAGIMACHI, R. (1969a) In vitro capacitation of hamster spermatozoa in follicular fluid. F. Reprod. Fert. 18, 275.

YANAGIMACHI, R. (1969b) In vitro acrosome reaction and capacitation of golden hamster spermatozoa by bovine follicular fluid and its fractions. F. exp. Zool. 170, 269.

YANAGMachi, R. (1970) In vitro capacitation of golden hamster spermatozoa by homologous and heterologous blood sera. Biol. Reprod. 3, 147.

YANAGimachi, R. \& Chang. M. C. (1964) In vitro fertilization of golden hamster ova. F.exp. Zool. 156, 361 .

YATVin, M. B. \& LeATHEM, J. H. (1964) Origin of ovarian cyst fluid: studies on experimentally induced cysts in the rat. Endocrinology, 75, 733.

Young, W. C. (1961) The mammalian ovary. In: Sex and Internal Secretions, Vol. 1, p. 449. Ed. W. C. Young. Ballière, Tindall \& Cox, London.

YoungLaI, E. V. (1971) Steroid content of the equine ovary during the reproductive cycle. $\mathcal{F}$. Endocr. 50, 589.

YoungLaI, E. V. (1972a) The influence of follicular fluid and plasma on the steroidogenic activity of equine granulosa cells. 7. Reprod. Fert. 28, 95.

YoungLAI, E. V. (1972b) Effect of mating on follicular fluid steroids in the rabbit. F. Reprod. Fert. 30, 157.

YoungLai, E. V., Edwards, R. G. \& Steptoe, P. C. (1972) The enzymatic activity of aspirates of preovulatory human follicles. Can. F. Biochem. 50, 233.

YoungLaI, E. V. \& Short, R. V. (1970) Pathways of steroid biosynthesis in the intact Graafian follicle of mares in oestrus. F. Endocr. 47, 321.

Zachariae, F. (1957) Studies on the mechanism of ovulation. Autoradiographic observations on the uptake of radioactive sulfate $\left({ }^{35} \mathrm{~S}\right)$ into the ovarian follicular mucopolysaccharides. Acta endocr., Copenh. 26, 215.

Zachariae, F. (1958) Studies on the mechanism of ovulation. Permeability of the blood-liquor barrier. Acta endocr., Copenh. 27, 339.

ZAchariae, F. (1959) Acid mucopolysaccharides in the female genital system and their role in the mechanism of ovulation. Acta endocr., Copenh. 33, Suppl. 47, p. 11.

Zachariae, F. \& Jensen, C. E. (1958) Studies on the mechanism of ovulation: histochemical and physico-chemical investigations on genuine follicular fluids. Acta endocr., Copenh. 27, 343.

ZAMBONI, L. (1972) Comparative studies on the ultrastructure of mammalian oocytes. In: Oogenesis. Eds. J. D. Biggers and A. W. Schuetz. University Park Press, Baltimore; Butterworths, London. 